\title{
MOLECULAR BASIS OF PLANT-SYMBIOTIC FUNGI INTERACTION: AN OVERVIEW
}

\author{
Anjana Singh \\ Central Department of Microbiology, Tribhuvan University, Kathmandu, Nepal.
}

\begin{abstract}
The intimate symbiotic relationships developed between mycorrhizal fungi and plants, since land colonization by the latter have led to an interdependence between these organisms for many basic processes. The fungi require plants to accomplish their life cycle. Plants depend heavily on mycorrhizal fungi for many different functions, such as mineral nutrition, and abiotic and biotic stress resistance. Substantial evidence has accumulated in recent years about how rational use of this microsymbiont could significantly contribute to decreasing use of fertilizer and pesticide in agriculture, forestry and flori-horticulture, especially, if combined with other beneficial soil microorganism. Symbiotic fungi act as major link between plants and soil, and should, therefore, be considered a central pivot for new strategies in the development of biologically-oriented agricultural practices.
\end{abstract}

To search for functional genes controlling fungal morphogenesis, infection process, metabolism of mycorrhizal roots, down regulation of defense- related genes in plants, are still in infancy, but with the advent of new molecular biology techniques, it is speculated not to be a far cry. And it is hope that it will cover the experimental and technical gap, still existing between the AM and other symbiotic systems which are experimentally more tractable. Plants with constitutively over-expressed defense related genes provide interesting material of determining how fungi contend with plant defense, although, how modification occurs in the expression of other genes in such plant is unclear. Molecular investigation of isogenic myc- mutants from pea and more recently from $M$. truncatula should also significantly advance our knowledge of plant and fungal gene expression essential to the symbiosis. Polypeptide analysis has already shown those compatible interactions in mycorrhizal pea and tobacco roots are dominated by de novo gene expression. Incompatible interaction in myc- mutant pea roots are mainly characterized by a down regulation of polypeptide synthesis, suggesting that maintenance of the activity of constitutively expressed plant genes may be important in the establishment of symbiotic fungus. The precise signals and molecular mechanism in establishing cellular and functional compatibility in fungal plant symbiosis are unknown. Rapid evolution in molecular techniques is facilitating the possibility of analyzing temporal and spatial gene expression in the two partners. Furthermore, cloning of genomic DNA has been achieved for uncultivable fungi and hybridization with homologous or heterologous probes is opening a vast new area of research for identifying genes essential to the different life stages of these organisms. Moreover, approaches like differential RNA display offers alternative strategies for studying the expression and regulation of those fungal genes underlying molecular mechanisms involved in the establishment, maintenance and functioning of the symbiosis.

Mycorrhizal research presents a challenging and exciting period when molecular and genetical tool can be used synergistically. The development of techniques permitting studies of the mycorrhizal fungi, which are at best difficult to culture, will expand our understanding of the value and functioning of below-ground root-fungal symbiosis. The author has screened a novel symbiotic fungus Piriformospora indica. This is a cultivable root colonizing and plant promoting fungus. Another fungi of relevance are species of Sebacina and Geosiphon. Some information on the interaction of $P$. indica with conventional non-host Arabidopsis thaliana is indicated. The author believes that there are many tools for the analysis of the genetic component of the specific biological question and further hopes that this article shall open vistas and thoughts for further challenging new research.

Key Words: Colonization; Microsymbiont; Gene expression; Piriformospora indica.

\section{INTRODUCTION}

Living together is one of the most prevalent phenomena in the biological world, especially in the plant kingdom and in the underground environment. Underground world also harbors one of the most common symbiotic associations between plant root and fungus called "Mycorrhiza" (Smith and Read 1995; Trappe 1996; Varma 1998, Varma et al. 2002). More than 6,000 fungal species are capable of establishing mycorrhiza with about 240,000 plant species, but relatively few anatomical types of plant-fungus interaction results from such impressive bio-diversity.

\section{TAXONOMY AND SYSTEMATICS}

Arbuscular mycorrhizae (AM) fungi are restricted to the order Glomales with three families having six genera, namely Glomus, Acaulospora, Gigaspora, Sclerocystis, Scutellospora and Entrophospora (Morton and Redecker 2001), which biotropically colonize the root cortex where large proportion of the mycelium occupies an endocellular position, differentiating into a highly branched haustoria, the arbuscules, which are the site of nutrient exchange. The recent work provides convincing evidence for a positive interaction of symbiotic fungus with several members of Crucifereae 
Table 1: Classification Scheme for Glomalean Taxa (c.f. Brundrett et al. 1996; Morton and Redecker 2001).

\begin{tabular}{|c|c|}
\hline \multicolumn{2}{|l|}{ ORDER } \\
\hline \multicolumn{2}{|c|}{ SUBORDER } \\
\hline & Family \\
\hline & Genus \\
\hline \multicolumn{2}{|c|}{ GLOMALES } \\
\hline \multicolumn{2}{|c|}{ GIGASPORINAE } \\
\hline \multicolumn{2}{|r|}{ Gigasporaceae } \\
\hline \multicolumn{2}{|r|}{ Gigaspora } \\
\hline & \multirow[t]{2}{*}{ Scutellospora } \\
\hline GLOMINEAE & \\
\hline \multicolumn{2}{|c|}{ Glomaceae } \\
\hline \multicolumn{2}{|r|}{ Glomus } \\
\hline \multicolumn{2}{|r|}{ Sclerocystis } \\
\hline \multicolumn{2}{|c|}{ Acaulosporaceae } \\
\hline \multicolumn{2}{|r|}{ Acaulospora } \\
\hline \multicolumn{2}{|r|}{ Entrophospora } \\
\hline \multicolumn{2}{|c|}{ Archaeosporaceae } \\
\hline \multicolumn{2}{|r|}{ Archaeospora gerdemannii } \\
\hline \multicolumn{2}{|c|}{ Paraglomaceae } \\
\hline \multicolumn{2}{|r|}{ Paraglomus occultum } \\
\hline \multicolumn{2}{|r|}{ P. brasilianrum } \\
\hline
\end{tabular}

(Kumari et al. 2003). The current concept on the classification of the Glomalean members is given in Table 1.

\section{HABITAT}

Mycorrhizal association is found in a broad range of habitats. These include ecosystem ranging from aquatic to desert (Neeraj et al.1991), from lowland tropical rain forest (Janos 1987) to high altitudes (Allen et al. 1987), and in the canopy epiphytes (Nadkarni 1985). AM fungi are found in nearly all soil where plants grow, including environments that are considered stressful to plant growth. In fact, mycorrhizas to have their greatest impact where plant grows, including environmental stress.

\section{PHYSIOLOGY AND BIOCHEMISTRY}

Fungal symbionts get shelter and food, i.e., reduced carbon (Singh et al. 2001) from the plant which in turn acquires and array of benefits ranging from better uptake of phosphorus and relatively immobile micronutrients, like zinc and copper and other minerals increase in nitrogen fixing capacity of leguminous plant species, salinity and drought tolerance, maintenance of water balance, increased rate of photosynthesis to overall increase in plant growth and development. Mycorrhizal plants show higher tolerance to high soil temperature and various soil and root borne pathogens (Azcon-Aguilar and Barea 1996). In eutrophic soil, these plants can take up nitrogen in the form of ammonia. Seedlings, which are colonized by these fungi, perform better during transplantation. The mycorrhizal plants are also more tolerant towards heavy metal toxicity (Samantry et al 1998a, b).

Recent insights even suggest that there is specialization among AM fungi affecting soil verses plant nutrition. AM fungal species of the genus Gigaspora appear to favor the fluxes of carbon compound from plant to soil biota, resulting ultimately in soil aggregation, while Glomus species tend to favor root colonization, plant growth and productivity through improved mineral nutrition. Little is known about the genetic make-up of AM fungi, which are recalcitrant to pure culture (Azcon-Aguilar and Barea 1996). Two distinct phenotypes were screened in Pisum sativum with altered infection pattern. Several different mutated loci have been distinguished among mutants, underlying the complexity and multigenic nature of plant control process. Plant defense responses, which are normally weakly activated during the symbiotic state, are strongly elicited by AM fungi in genetically altered, resistant hosts suggesting control over defense gene expression during establishment of successful symbiosis. Modifications are also induced in the fungal symbionts during colonization of the host tissue, which include changes in wall metabolism and protein expression. Chemical mutagenesis has further revealed that AM symbiosis is established through a multistep process consisting of a “cascade of recognition events" leading to a complete morphological and physiological interaction of two partners.

\section{HOST SPECIFICITY}

The relationship of the AM fungi with the host plant is obligatory (Gianinazzi-Pearson et al. 1998). They exhibit little host specificity in nature. Individual species may infect plant species belonging to different genera, families, orders and classes. It has been estimated that $85-90 \%$ of the approximately 2,31,000 species of angiosperms (Steward and Press 1990) form this symbiosis despite their being only approximately 150 described species of AM fungi (Morton and Benny 1990). For an AM plant symbiosis to be established, molecular signaling events must occur that lead to various physiological and anatomical changes in both symbionts. Thus, the lack of AM fungi specificity might occur if the signal molecules necessary at the various stages of infection were produced by all mycotrophic plant species (Smith and Gianinazzi-Pearson 1988). Alternatively, a variety of signals may be capable of initiating the same signal molecule governing the formation of symbiosis (Lynn and Change 1990). However, they do not establish symbiotic relationship with Lupinus, a member of a predominately mycorrhizal family leguminaceae (Gianinazzi-Pearson et al. 1996a; Gollotte et al. 1996b). The complexity of the life cycle of the fungus within the plant indicates that compatibility cannot be the result of a single recognition event or a unique gene.

The cellular interaction leading to reciprocal morphofunctional integration between symbiont during mycorrhiza establishment must be based on highly evolved physiological and genetical coordination between the fungus and host, the timing and nature of which is crucial to the overall outcome of the symbiosis (Gianinazzi-Pearson et al. 1996a). Mycorrhiza fungi are not a monolithic group affecting plants only by 


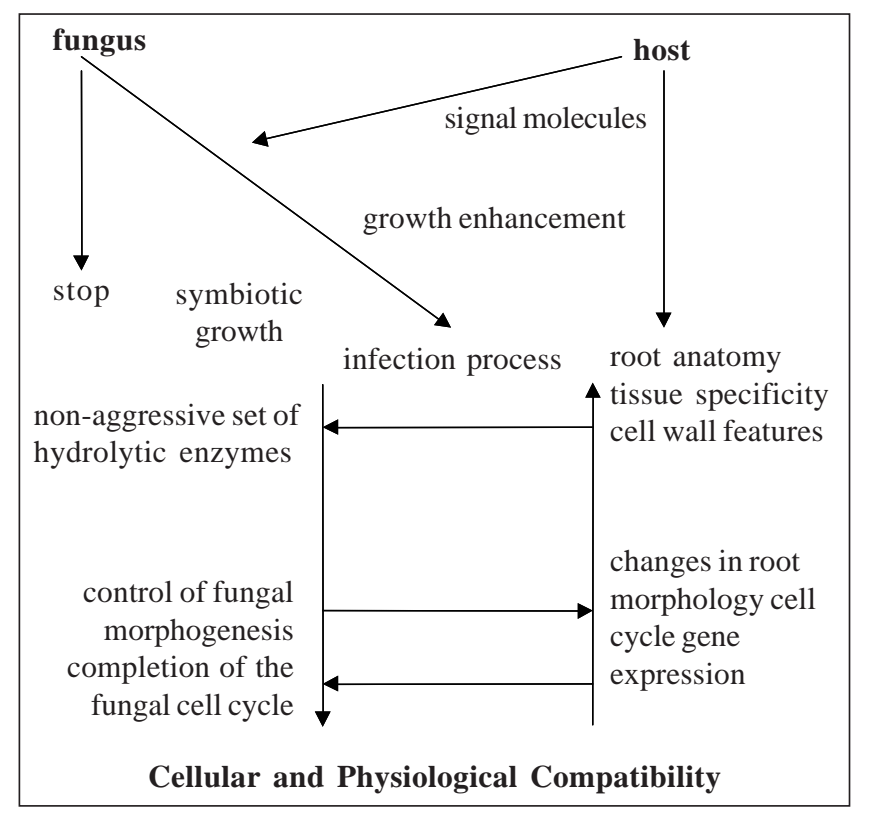

Fig. 1: An illustrative view of the different steps of the plant-fungal interaction at cellular level (c.f. Bonfante-Fasolo and Perotto 1992).

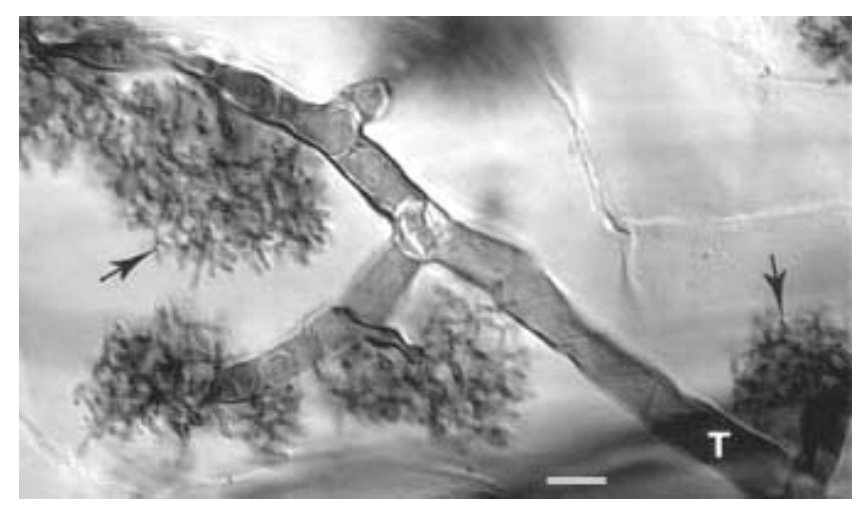

Fig. 2: Typical Arbuscules of Gigaspora margarita with an elongated trunk hypha (T) and tufts of fine branch hyphae (arrows).

their presence or absence, but highly variable organism that can elicit a variety of host responses (Varma 1998). Arbuscular mycorrhizal fungi interact with almost $90 \%$ of the terrestrial plants (Smith and Read 1997; Varma et al. 1999), however, only limited members of plant community have failed to interact and they belong to the family of Amaranthaceae, Chenopodiaceae, Cyperaceae Junaceae, Proteaceae or with lupines and Crucifereae, etc (Denison et al. 2003). A careful perusal of the literature indicates that this statement may not be true (Leake 1994; Tester et al. 1987). Denison et al (2003) have emphasized that model systems are also important as a new research tool to understand the co-operation between microbes and the plants.

\section{ESTABLISHMENT OF SYMBIOSIS}

A generalized life cycle of a mycorrhizal fungus is not complicated in most cases, but respond in a highly plasmatic manner to its surrounding environment. The production of new propagules is a critical phase in the life cycle of AM fungi. They include asexual and sexual spores, as well as germinating or extraradical hyphae associated with dormant, senescing or detached roots (Wilson and Tommerup 1992). Asexual spores are regarded as the dominant propagules for AM fungi. Tommerup and Sivasithamparam (1990), however, observed Gigaspora decipines that produced zygospores under natural and laboratory condition, in both the presence and absence of a host plant. The taxonomy of the AM fungi has mostly relied on the morphology and nature of the resting spores, creation of the new order of Glomales (Morton and Benny 1990), and description of six genera and atleast 130 species there in (Morton and Redecker 2001) are principally based on the spore structure. The root of compatible host are infected by germ-tubes arising from spores, by hyphae growing from other propagules or by external hyphae connected to active AM. The hyphal growth from germinating spores is dependent initially upon its own nutrient supply but stimulation of further fungal growth from germinating spores is by root exudates of a compatible plant host (Fig. 1). Becard and Piché (1989) used the in vitro dual culture system with transformed roots to distinguish two fungal growth stages. The first is triggered by the presence of the root and depends on the spores. It ceases progressively and is followed by the second growth stage, which is independent of the spore and depends on the establishment of an infection unit inside the plant. The molecular mechanisms limiting the first state are not understood, though a number of hypotheses have been formulated. Depletion of the spore's reserves, lack of DNA replication or mRNA synthesis within the elongating hyphae and alternations in cell-wall synthesis may influence hyphal growth (Bianciotto et al. 1989; Burggraff and Beringer 1989).

The formation of appressoria, which is formed at the point of contact by the hyphal tip, is one of the first signs that recognition between the plant and the fungus has occurred (Bonfante and Perotto 1992). It has been shown that the formation of appressorium is induced by the root exudates produced by a compatible host plant whereas root exudates from non-host such as lupin stimulate only hyphal elongation but no formation of true appressoria in G. mosseae (Giovannetti et al. 1993). Appressorium is a structure, which has the capacity to adhere to host surface and ability to germinate and penetrate the host. Formation of appressorium is a decisive event in the fungal recognition and infection of a host. It is first cell-to-cell recognition step during AM fungus-plant-host restriction. It form either on the surface of an epidermal cells (or exodermic cell if the epidermis has degenerated), or more rarely along a root hair (Table 2).

After the formation of appressoria, the hyphae elongates intercellularly and the root cortical cells and gets differentiated in to a highly branched structure called arbuscule (Fig. 2), through which the bi-directional flux of nutrients takes place between the partners. Peri-arbuscular membrane, which is also a specialized structure formed at the site of arbuscular formation, consists of the membrane of the both partner (Gollotte et al. 1996a) and facilitate the transport in both direction between the partners. Another significant feature of AM establishment is the restriction of hyphae in the cortical cells of root. Only specific root tissues such as epidermal and cortical tissues are colonized, whereas others such as 
Table 2: Postulated Promises made by Symbiotic Fungi

\begin{tabular}{|c|c|}
\hline plant production & leaf physiology \\
\hline reduced fertilizer and pesticides & postpone leaf dehydration \\
\hline nutrient acquisition & alter leaf osmotic potential \\
\hline plant size or biomass & $\begin{array}{l}\text { alter the number of } \\
\text { photosynthetic units }\end{array}$ \\
\hline improve soil/root contact & photosynthetic storage \\
\hline affect soil structure & export rates \\
\hline create the skeletal structure & dissimilar symplastic solute \\
\hline create microaggregate structures & effective scavenging of soil water \\
\hline higher rhizosphere & effect on osmotic adjustment \\
\hline alter host water relations & photosynthetic rates \\
\hline profound ecological and & drought responses \\
\hline agricultural consequences & transpiration rates \\
\hline plant establishment & stomatal conductances \\
\hline vigor and productivity & intrinsic leaf hydraulic \\
\hline survival in water-limiting & osmo-protect enzymes \\
\hline conditions & alter nodule number and activity \\
\hline alter root length & enhance phosphorus acquisition \\
\hline root architecture & alter total protein \\
\hline root/shoot ratio & $\begin{array}{l}\text { alter morphological and } \\
\text { phenological effects }\end{array}$ \\
\hline resistance to water flow- & alter leaf abscission \\
\hline from bulk soil to pararhizal zone & $\begin{array}{l}\text { alter leaf drop, necrosis and } \\
\text { senescence }\end{array}$ \\
\hline across perirhizal zone & alter leaf movements \\
\hline across the cortex to the root xylem- & alter recovery from wilting \\
\hline root xylem to the stem- & $\begin{array}{l}\text { alter the relative allocation of } \\
\text { biomass }\end{array}$ \\
\hline to the leaf surface & $\begin{array}{l}\text { bioprotective agent against } \\
\text { pathogens }\end{array}$ \\
\hline re-vegetation of landscapes & reducing the susceptibility \\
\hline $\begin{array}{l}\text { biological hardening of tissue } \\
\text { culture- raised plants }\end{array}$ & $\begin{array}{l}\text { increasing the tolerance to } \\
\text { pathogens }\end{array}$ \\
\hline alter rate of water movement & protection against nematode \\
\hline effect on tissue hydration & $\begin{array}{l}\text { enhance the release of ABA from } \\
\text { leaf mesophyll }\end{array}$ \\
\hline $\begin{array}{l}\text { suppressing nematode reproduction } \\
\text { and infection }\end{array}$ & promotion of drought avoidance \\
\hline $\begin{array}{l}\text { alternative to costly soil disinfection } \\
\text { affect water balance in some non- } \\
\text { hydraulic way }\end{array}$ & higher nitrogen assimilation \\
\hline altering hormonal relations & better nitrogen nutrition \\
\hline symbiotic fungi produce ABA & alter soluble proteins \\
\hline affect host balances of ABA this & amino acids \\
\hline acts as drought-induced & nitrogenous enzymes \\
\hline non-hydraulic root signals & glutathione \\
\hline inhibits stomatal opening & glutathione disulphide \\
\hline symbiosis modify xylem $\mathrm{pH}$ & glutathione reductase \\
\hline influence putative signal & $\begin{array}{l}\text { glucose-6-phosphate- } \\
\text { dehydrogenase }\end{array}$ \\
\hline root-to-shoot communication & proline- indicator of drought \\
\hline changes in the flux of protons & carbohydrate metabolism \\
\hline \multicolumn{2}{|l|}{ changes in apoplastic $\mathrm{pH}$} \\
\hline increased $\mathrm{pH}$ of leaf apoplast & \\
\hline
\end{tabular}

meristem or vascular tissue are resistant to mycorrhizal infection (Bonfante and Perotto 1992).

\section{FUNCTIONS OF AM FUNGI}

AM fungi are obligate biotrophs, which derive nutrients from living cells of the host plants. Mycorrhizal fungi are the key member of the soil microbiota and conduct activities which are crucial to plant establishment, development, nutrition and health (Azcon-Aguilar and Barea 1992; Lindermann 1992). Mycorrhizal fungi actively develop within the rhizosphere, as stimulated by root exudates, plant residues and other organic substrates from plant. Plant benefits through an increased availability of plant nutrients, improvement of nutrient uptake and protection against root pathogens. AMF are also known to develop bridges connecting the root with the surrounding soil particles to improve both nutrient cycling and acquisition by the plant and soil structure (Table.2) (Millar and Jastrow 1992a, 1992b; Varma 1999). Mycorrhizal fungi enable the plant to cope with cultural or environment stress and play a key significant pole in sustainable soil-plant systems (Barea et al. 1993). AMF mycelium acts in a close “cause-and-effect interchange” of mineral nutrients, carbon compounds signals between the plant and rhizosphere populations and soil aggregation. Mycorrhizal association helps in nitrogen fixation in leguminous plants because the fixation process is, however, dependent on the supply of phosphorus and other nutrients.

Mycorrhizae link the biotic and geochemical portions of the ecosystems, but it is extremely difficult to measure their impact on ecosystem responses. They are believed to contribute to biogeochemical cycling of nutrients more than by simply providing a greater hyphal surface area for scavenging nutrient elements that may be relatively immobile in soil or in short supply. Mycorrhizae are a close, stable and permanent association of a root of a higher plant and a fungus where no apparent damage results to either partner, though there may be morphological changes. In the mycorrhizal host, the root systems usually consist of mycorrhiza and uncolonized roots. Mycorrhizal fungi and other populations of the rhizosphere and root or mycorrhizal surface, have significant effects on the physiological processes of their hosts, especially in terms of absorption, by virtue of their position. They may also inhibit or perhaps encourage soil-borne pathogens. They exist at the interface of soil and root or mycorrhiza and so may alter the soil atmosphere and by absorption, release or change of form, of $\mathrm{pH}$, the availability of chemical compounds in the root region. The value of $\mathrm{pH}$ is not affected only by root exudates, but also by nutrient uptake by the root system, transport processes and by the release of $\mathrm{H}^{+}$associated with root growth. The largest changes are found to be on the root surfaces. The prominent changes in $\mathrm{pH}$ values in acidifying systems are found between $\mathrm{pH} 4.5$ and 6.0. These changes are evident up to a distance of $2 \mathrm{~mm}$ from the root surface.

The fungal hyphae first colonize the surface, produce appressoria and later enter the cells, transverse through the cells and produce structures, arbuscules and vesicles, normally observed for AM fungi. The sequence of events leading to successful root colonization by AM fungi is depicted in (Fig. 3).

\section{PLANT DEFENSE RESPONSES AT AN EARLY STAGES OF INTERACTION}

The rapid recognition of a potential invader is a prerequisitefor 


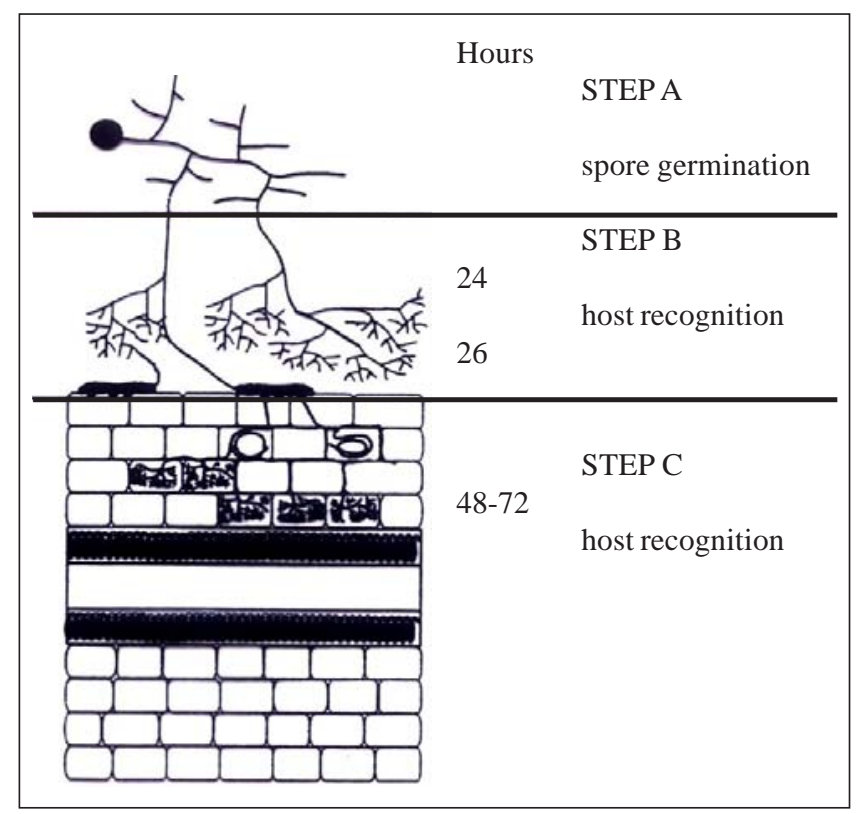

Fig. 3: The spatio-temporal development of arbuscular mycorrhizal symbiosis. Step A: A germinated spore show a linear growth pattern, consisting of branches extending in all directions, functional for soil exploration and for an efficient exploitation of resources. Step B: As early as $24 \mathrm{~h}$ after the perception of host derived signals, a different hyphal growth pattern is expressed, functional to the location of infection sites. $36 \mathrm{~h}$ after the beginning of symbionts interaction, dramatic morphogenetical changes occur in hyphal tips, leading to the formation of appressoria. Step C: After root penetration, intercellular hyphae colonize the root, producing intracellular branched structures, the arbuscules, as early as $42-72 \mathrm{~h}$ after the beginning of the interaction.

the initiation of an effective defense response by the plant. This is achieved through the recognition of specific signal molecules also known as elicitors. Elicitors can be secretedfrom the microbe (exogenous elicitors) or generated as a result of physical and/or chemical cleavage of the plant cell wall (endogenous elicitors). After perception of an elicitor, a number of biochemical changes contribute to the early response in host cells. These processes include changes in the ion permeability of the plasma membrane, the activation of plasma membrane-bound enzymes, the activation of kinases, phosphatases, phospholipases, and the production of signal molecules, including active oxygenspecies. The result of these processes is the transcriptional activation of defense-related genes.

\section{INFLUENCE OF THE HOST GENOME IN THE ESTABLISHMENT OF DIFFERENT STRUCTURES}

Pea mutants (nod) which can not form nitrogen fixing nodules, were allowed to be infected by AM fungi, and was found that it was not able to colonize and were termed as myc mutants (Gianinazzi-Pearson et al. 1991). This successful colonization was not seen when the AM fungi are allowed to infect the mutant, it is seen that, in such mutants appressoria formation is there but no hyphal elongation occurs and are called early mutants. In the second set, appressoria formation as well as hyphal elongation are seen but no true formation of arbuscules and are called as the late mutant. In both the cases, it has been found that there is lot of deposition of $\beta-1,3$ glucans at the point of contact, and there is a thickening of cell wall of the root cells. This reflects that the defense system of the plant has been elicited, which is not the case in a compatible host, where the defense-related genes are transiently and weakly expressed whenever there is a successful colonization (Gianinazzi-Pearson et al. 1996a). These mutants, when allowed to be infected by pathogenic fungi, were not able to resist infection. From this, it can be concluded that some specific symbiotic genes are there which are responsible for successful symbiotic association, and they can not confer any resistance to any pathogenic infection, thus confirming specificity for symbiosis (Gianinazzi-Pearson 1995). It has also been observed that the formation of different morphological structures by the fungi partially under the control of host genome and successful colonization is possible only when specific plant genes are functional. These genes seem to have a general mode of action, as their mutation affects at least two types of plant-microbe interaction, nodules and mycorrhiza.

\section{COLONIZATION CONSEGUENCE OF ENZYMATIC AND MECHANICAL PROCESS OR BOTH?}

Mechanical pressure is thought to help the biotrophic fungi, while penetrating a host plant root, which allows the fungi to perforate the host wall through formation of a penetration peg. Some wall components, such as melanin, are considered to play an important role in increasing the hydrostatic pressure, since they act to trap solutes within the appressoria, causing water to be absorbed because of the increasing osmotic gradient (Howard and Ferrari 1989).

Pathogenic interaction seem to be under the control of cell wall degrading enzymes, since the plant cell wall, the first barrier to overcome, may be partially degraded by enzymes of microbial origin (Walton 1994). Investigation has demonstrated the production of pectinase, cellulase and lyase (Perotto and Bonfante 1997; Varma 1999; Varma and Bonfante 1994). Among these, polygalactouronases are considered to be important determinants of pathogenecity. They allow the fungus to colonize the host tissues and to obtain nutrients from the degradation of pectic substrates (Varma 1998). In contrast, the infection process by biotrophic fungi is characterized by a low and regulated production of cell wall degrading enzymes by the fungus. In Uromyces viciaefabe, for example, acidic cellulase are the first enzymes to be produced, followed by a sequential production of pectin esterase, neutral cellulase and polygalactouronate lyases. AM fungus (G. mosseae) seems to follow the same sequence, production of small amount of cell wall degrading enzymes such as pectinase and cellulase (GaricaRomero et al. 1991a,b). When homogenates from leek mycorrhizal roots were compared with non-mycorrhizal root no quantitative changes in polygalactouronase activity were found. The biochemical data show that there are polygalactouronase expressed solely during the symbiotic stage, while the immunolocalization result suggests that the enzymes cannot be directly correlated with their activity. Pectin of host origin, which might be suitable substrate for the polygalactouronase, could also be localized at the interface compartment (Bonfante et al.1991). It is suggested that the fungus might use pectin as a food source (Varma et al. 2001). 
Production of cell wall degrading enzymes is, however, limited both in quality and quantity. AM fungi do not penetrate the endodermis or any other walls, contain suberin and lignin, indicating that they cannot degrade these compounds. The role of these enzymes in infection, especially endo-and exopolygalactouronases as well as glucanases still needs to be determined. The low rate of production of cell wall hydrolytic enzymes suggests that AM fungi penetrate the root's surface mostly by mechanical force. Appressoria with well-melanized walls produce hyphae, which tend to progress by growing between root epidermal cells rather than by crossing their outer walls. Once inside the roots, many fungi produce intercellular hyphae which run within huge air channels, producing penetration peg and causing only limited and subtle changes in the structure of the host wall and produce very limited amounts of hydrolytic enzymes at this stage (Brundrett and Kendrick 1990).

It seems that AM fungi colonize the root tissues of their host plant by means of a combination of both mechanical and enzymatic mechanisms (Fig. 4). Very weak and localized production of enzymes might ensure that viability of the host is maintained, defense responses are not triggered and a high degree of compatibility is reached.

\section{MODIFICATIONS IN FUNGUS AND HOST CELL ARCHITECTURE}

\section{Modifications in the fungus}

Besides formation of the regular appressoria and arbuscules by the fungus in a compatible interaction, major modification also occurs in fungal cell wall compartments, such as the cell wall, which becomes progressively thinner as infection develops in the roots and the cytoplasm changes its organization. Changes also occur in the storage components from lipid to glycogen, and the nuclear reorganization can change the physico-chemical properties of the fungal wall, resulting in alternation of its permeability and resistance to turgor pressure, thus, influencing molecular exchanges between the two symbionts (Bonfante and Scannerini 1992). Specific fungal enzyme activities are also known to change during plant tissue infection, such as the expression of a vacuolar alkaline phosphatase (Tisserant et al.1993). The mechanisms, controlling differentiation of AM fungal structure, in particular, the arbuscular, are so far not adequately understood.

\section{Modifications in the plant}

A number of regulatory mechanisms of plant defense response have been described during the establishment of the arbuscular mycorrhizal symbiosis, including elicitor degradation, modulation of second messenger concentration, nutritional and hormonal plant defense regulation, and activation of regulatory symbiotic gene expression. The functional characterization of these regulatory mechanisms on arbuscular mycorrhiza, including cross talk between them, will be the aim and objective not worked out. Formation of arbuscules inside the cortical cells of root by the AM fungi also induced several morphological modifications in the cell's
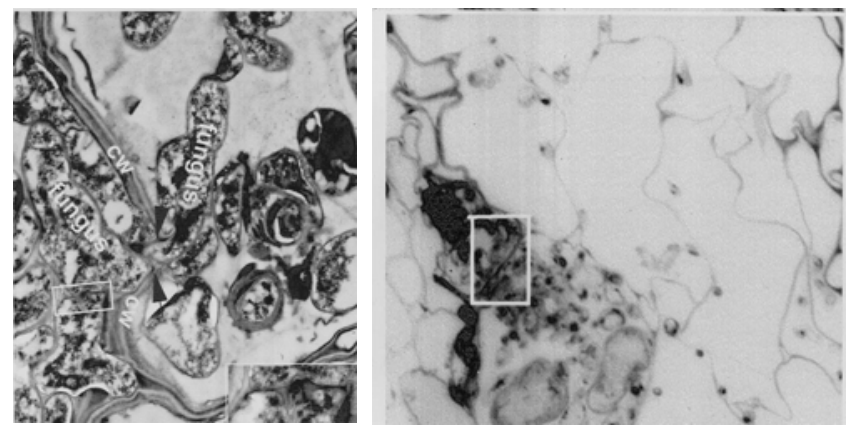

Fig. 4: Penetration of cell wall by Piriformospora indica within the cortex of transformed carrot root organ cultures, CW; Cell wall: Arrow; the point of entry by the fungus. Inset shows a magnified view of the fungal colonizing the root.

architecture. Dramatics modification of host cell architecture such as invagination of the plant plasmalema, fragmentation of the vacuoles, disappearance of amyloplast and increase in the number of organelles, such as golgi bodies (Bonfante and Perotto 1992). The presence of fungus radically and effects the morphology of the plant nucleus, which maintains its ploidy, but increases in size owing to unfolding of its chromatin (Berta et al. 1990). Position of the nucleus is also affected, which moves from a peripheral position, typical of uninfected cell, to a central position in infected cells. This nuclear movement as well as many of the responses of the plant to fungal penetration probably results from modification in the organization of the plant cytoskeleton (Kobayashi and Kunoh 1992).

\section{CREATION OF APOPLASTIC COMPARTMENT}

One of the most important events that mark successful colonization of plant cells of plant cells by AM fungi is the formation of an interface compartment at the contact area between plant and fungal cell surfaces. It is composed of the membrane of both partners, separated by an apoplastic region and assumed to have a role in allowing a two-way exchange of nutrients (Bonfante and Scannerini 1992; Smith et al.1994). When root cells are colonized by AM fungi, the host plasmalemma invaginates and proliferates around the developing fungus around the arbuscules. Apoplastic material is laid down between the invaginated plasma membrane and fungal cell surface, creating a new compartment. This compartment is structurally complex since it is composed of the host membrane, the interfacial material, the fungal wall and the membrane (Gollotte et al. 1996a). The material surrounding fungal branches topologically continues with the host wall, but its texture undergoes modification during arbuscules development. The material appears electron dense at the penetration point; it thins around arbuscular branches and thickens again around collapsed branches. It has a zone of high molecular complexity, molecules common to the plant primary wall, such as b- 1 , 4 glucans, nonesterfied polygalactouronase, hemicellulose such as xyloglucans, protein rich in hydroxyproline (HRGPs) and arabinogalactan proteins have been found in many different plant AM fungi combinations (Bonfante-Fasolo et al. 1991; Gianinazzi-Pearson et al. 1992; Gollotte et al. 1996b) (Fig. 5). Chitin and b-1, 3 glucans were not detected in the interfacial material, 
whereas they are detected in the wall of many AM fungi (Bonfante and Perotto 1990).

Current model assumes that plant cell wall consist of three interwoven domains: a network of cellulose and hemicellulose, another of heterogeneous pectin's and a third of proteins. The presence of these molecules typical of the primary plant cell wall indicates that the newly synthesized membrane, termed the perifungal membrane, retains the enzymatic machinery involved in the synthesis (cellulose) and secretion (pectins, hemicellulose, HRGPs) of cell wall material. In mycorrhizal association, because of its position around the fungus, the term perifungal membrane is suggested, which has a wider meaning than peri-arbuscular membrane limited to the membrane surrounding the arbuscular branches. The ATPase activity, revealed in the perifungal membrane might be very important in terms of nutrient transport. Part of this activity is attributable to an $\mathrm{H}^{+}$/ATPase present in the perifungal membrane invaginated around the arbuscules, but cytochemically undetectable along other plant membranes. But its activity is absent around aborted arbuscules formed by the late pea mutants (Gianinazzi-Pearson 1995).

The two-way transfer between the plant and AM fungi also involves fungal membrane and have consistent $\mathrm{H}^{+}$-ATPase activity and exchange occurs across both the arbuscule interface, and the interface produced by cortical cell walls and intercellular hyphae. The presence of $\mathrm{H}^{+} /$ATPase seem to be typical of mutualistic symbiosis as it is also found on the plant membrane surrounding bacteria inside the nodule (Brewin 1990). By contrast, no active membrane-associated ATPase was found on the membrane surrounding haustoria in plant-pathogen interaction, which might explain the unidirectional nutrient influx towards the fungus observed in pathogenic interactions (Smith and Smith 1990).

\section{GENESIS OF INTERFACIAL COMPARTMENT}

Formation of the interfacial compartment involves de novo synthesis of cell wall and membrane molecules. In legume root nodules, the mechanisms by which membrane proliferation is initiated or by which vesicle transport towards the infection thread or the peribacteroid membrane occurs still unknown. However, Cheon et al. (1993) were able to demonstrate the importance in plant membrane synthesis of plant homologous of Rab1P and Rab7P, small GTP-binding

\begin{tabular}{|lc|}
\hline $\begin{array}{l}\text { fungal plasma } \\
\text { membrane } \\
\text { fungal wall }\end{array}$ & \begin{tabular}{c} 
glucans, protein, ATPase \\
\cline { 2 - 2 }
\end{tabular} \\
\cline { 2 - 2 } $\begin{array}{l}\text { glucans, proteins, } \\
\text { chitin polymer }\end{array}$ \\
\cline { 2 - 2 } $\begin{array}{c}\text { 1,4 glucans, pectins, cellulose, proteins, } \\
\text { periarbuscular } \\
\text { membrane }\end{array}$ & $\begin{array}{c}\text { glucans, proteins, peribacteroid membrane } \\
\text { glycoconjugates } \\
\text { glycoconjugates,neutral phosphates, } \\
\text { ATPase }\end{array}$ \\
\hline
\end{tabular}

Fig. 5: Diagrammatic representation of the distribution of molecules characterizing the arbuscular interface (c.f. Gollotte et al. 1996). proteins involved in vesicular transport found to be essential for the development of the peribacteroid compartment in effective symbiosis. Their results suggest that both these proteins are also essential for the development of peribacteroid compartment in effective symbiosis. Refined analysis similar to those developed for nodules are not yet available for the interfacial membrane, although an accurate quantitative analysis has indicated in arbuscular-containing cells a 3.7fold increase in host plasmalema (Alexander et al. 1989).

Morphological and immunological studies allow us to characterize the interface zone as a new compartment, which is the structural expression of the symbiotic status. Many membranes and wall molecules, occurring in the interface, are also found in the host plasma membrane and wall, although the morphology of the two compartments has distinct feature in the interface. The presence of the fungus in the plant cell seems to affect only the assembly and not the expression of molecules usually present at the host cell surface.

\section{CHEMICAL MESSENGERS AT PRE-INFECTION STAGE}

Mycorrhiza is regulated by water-soluble (mono and disaccharide's, amino acids, organic acids, flavonoids, nucleotide and enzymes) (Rovira 1996) and volatile exudates (alcohols, ketones, esters, phenols, terpenoids, organic acid) and by surface-bound recognition molecules. Volatile exudates form the host are more likely to be involved than others in stimulation of spore germination, germ-tubes growth, and directionality. Volatile compounds are more favored candidates because they are less likely to get inactivated by soil microorganisms and can move to a greater distance than the water-soluble exudates. Water-soluble exudates may function similarly but over shorter distance. In addition, it may provide the fungi with energy-containing compounds or essential nutrients to stimulate branching and allow the fungus to colonize the plant (Koske and Gemma 1992). Growth of Gigaspora margarita is enhanced eight fold by the simultaneous presence of root volatile and exudates diffusing through a dialysis membrane (molecular weight cut-off 12,000 to 14,000) long hyphae (about $300 \mathrm{~nm}$ ) were measured after 40 days in culture. By contrast, these factors had little or no effect when added separately. However, $0.5 \% \mathrm{CO}_{2}$ was able to replace root volatile compounds, suggesting that the $\mathrm{CO}_{2}$ produced during respiration by growing roots stimulates AM fungal growth (Becard and Piché 1989).

Surface-bond recognition molecules both on fungus and on the host are likely to be important when the fungi encounter plant cell surface, including the middle lamella. Different phases of colonization may be expected to be regulated by different groups of compounds (Koske and Gemma 1992).

\section{FLAVONOIDS AS SIGNALS}

Flavonoids are one of the signal molecules in Rhizobiumlegume interaction in which they activate the nod gene of Rhizobium and play a role in the establishment of successful interaction. Rhizobial nodulation factors induce the secretion 


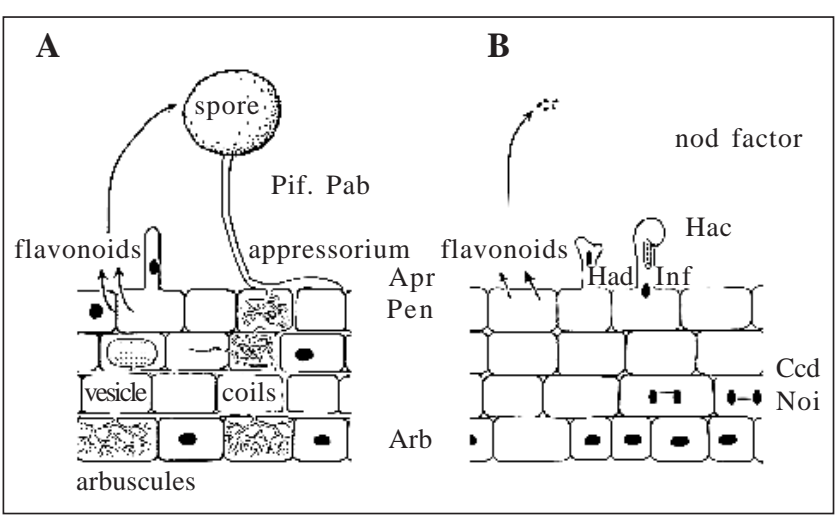

Fig. 6: Diagrammatic illustration of mycorrhiza and nodule development. (A) Mycorrhiza formation. Flavonoids released from the host stimulate spore germination (Germ), pre-infection growth (Pif), and hyphal branching (Pab). Later, appressoria (Apr) form and hyphal branches colonize the root. Some hyphae penetrate cortical cells (Pen), and may form coils or arbuscules (Arb). (B) Early stages of nodule development. Flavonoids from the root induce rhizobial nod genes. Nod factor is synthesized and stimulates root hair deformation (Had). Firm attachment of compatible rhizobia leads to root hair curling (Hac) and infection thread formation (Inf). Cellular divisions in the cortex (Ccd) trigger nodule initiation (Noi) (c.f. Hirsch and Kapulnik 1998).

of flavonoids and stimulates mycorrhizal infection in soybean. They are also thought to play an active role as signals in mycorrhizal association as its presence increases spore germination and hyphal elongation and branching. However, Becard et al. (1995) has demonstrated that maize mutants, which do not secret flavonoids, are regularly colonized by AMF. All these results seem to suggest that flavonoids, together with their related molecules, influence fungal growth (Fig. 6), but are not the general signals required for the establishment of mycorrhizal symbiosis (Balaji et al. 1995). Therefore, although their role as specific signals between symbionts seems improbable, their enhanced synthesis may have other unsuspected function in mycorrhizal interactions.

\section{PHENOLIC COMPOUNDS AS SIGNALS}

Among the exudates that promote fungal growth, plant phenols have been investigated as possible candidate as they are important transcriptional signals in other plant/soil microbe interaction (Peters and Verma 1990). Hesperitin, naringenin and apigenin stimulate the hyphal growth of $G i$. margarita. In other experiments, naturally released phenols have been identified and their effect has been tested on the growth of germinating spores of Glomus spp. (Nair et al.1991; Siquerra et al. 1991). The positive effect of the flavonols increased in the presence of $2 \% \mathrm{CO}_{2}$ After testing several related chemical structures, the author suggested that the hydroxyl group in position 3 is essential to confer stimulatory activity on the molecule (Becard and Piché 1992). The host, carrot (Daucus carrota L.) and non-host, sugar beet (Beta vulgaris), were examined to determine whether phenolics, which are associated with plant cell walls and cytoplasm themselves, stimulate hyphal growth or signal the presence of a compatible root by allowing to interact with two AM fungi, i.e., Gi. gigantia and Gi. margarita. It was found that the host exudates were not always stimulatory for successful interaction and non-host exudates were not always inhibitory. Also the responses differed at different concentration of these compounds and some cell wall associated phenolics have yet to be identified and their effects are to be studied (Nagahashi et al. 1996).

(a) symbiont responses to host-derived signals are not modified with host age, symbiont stage or status.

(b) host derived signals either consist of small molecules (less than 500 Da in weight) or do not consist of chemical diffusates (Giovannetti et al. 1996).

\section{PLANT-MICROBE SIGNALING PATHWAY}

During pathogenesis of plants $A$. tumefaciens transfers a portion of its own genetic material into plant cells and this integrates into the plant genetic material, eventually causing the crown gall tumor (Fig. 7). The interaction of the bacterium and its plant host can be viewed as a programmed series of signals and responses to those signals that are exchanged between the two organisms. Strikingly, many of the signaling pathways employed by A. tumefaciens during plant pathogenesis is shared with microbes that pathogenize animals, as well as with other symbiotic microbes.

\section{PHYSICALLY SEPARATED INTERCELLULAR COMMUNICATION IN MICROBES}

Bacteria have been shown to use intercellular signaling mechanism to regulate gene expression in response to a changing environment. Many bacteria, including $A$. tumefaciens produce chemical signals, acylated homoserine lactones that act as population density cues, and regulate a variety of processes important for microbial growth. This process is generally known as quorum sensing. Each communication system consists of a signaling molecule (autoinducer) and the corresponding sensor. Recently it has been observed that there is a presence of a novel intercellular communication mechanism that uses some form of physical signal (Matsuhashi et al. 1996). The growth promoting effect observed with this signaling system can occur between cultures separated by plastic and iron barriers. It is concluded that the signal represents a form of biological 'sonic' waves.

In A. tumefaciens quorum sensing regulates its behavior while in association with host plants. Acyl HSLs are synthesized by acyl HSL synthases, all members of a conserved group of proteins called the LuxI family. Likewise, the acyl HSL is perceived via the activity of intracellular receptors called LuxR-type proteins.

\section{ROLE OF RHIZOBACTERIA}

Rhizobacteria usually live in microcolonies where the availability of iron is restricted. Furthermore complexity arises through the organic acid released by plant root and presence of siderophores and phytosiderophores. PGPR (Plant growth promoting rhizobacteria) release pyoverdines that make siderotyping. Available evidences demonstrate that AHL ((Nacyl-L-homoserine lactone) molecules act as signal for communication between cells of different bacterial species in 
the rhizosphere. PGPRs secrete EPS (Exopolysaccharide) this EPS help in escaping unfavorable conditions. These EPS also serve two functions.

Their role in rhizosphere soil aggregation.

Putting a check on the spread of damping-off pathogens.

An overall view of the interaction of bacteria interacting in rhizospheric soils, roots and with fungal hyphae 'mycorrhizosphere' and their influence on symbiosis is presented in (Fig. 8).

\section{MECHANISM}

Fluorescent Psuedomonas species secrete a variety of antifungal molecules like- pyrrolnitrin, pyoluteorin, tropolone, pyocyanin, phenazines, and 2,4-diacetylphloroglucinol (phl). Many PGPR secrete ACC Deaminase which lowers ACC level in root of the plant, colonized by PGPR bacteria; this results in promotion of root elongation thus lowering of plant ethylene level.

Compatible or susceptible disease interactions are characterized by increased ethylene level and therefore the reduction in ethylene level should lead to disease reduction. The germinating mycelium of AM fungi may be influenced by other symbiont or by plant growth promoting organisms (Bethenfalvay and Lindermann 1992; Perotto and Bonfante 1997). Bianciotto et al. (1996) investigated whether direct physical interaction occurs between AM fungi and plant growth promoting rhizobacteria (PGPRs), some of which are

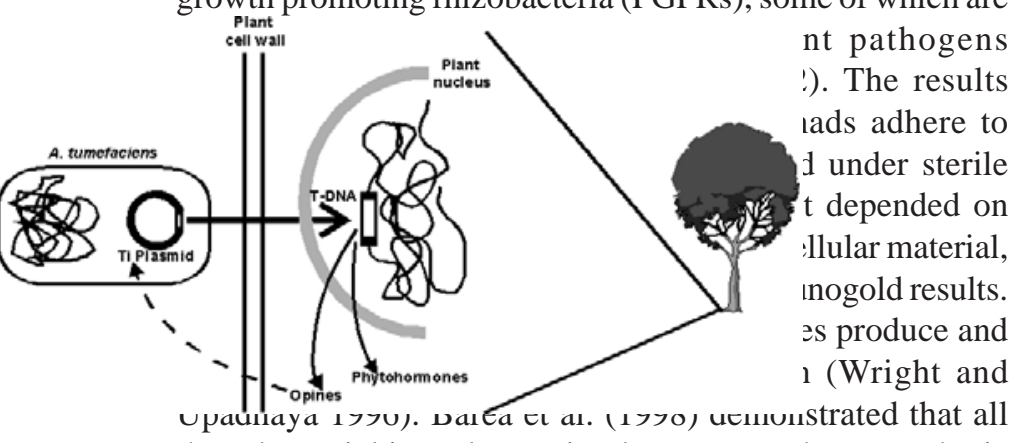
these bacterial inoculants stimulate in vitro the saprophytic growth of AM fungi (Bianciotto and Bonfante 1998).

\section{HOST DEFENSE RESPONSE}

When a plant is challenged by microorganisms or is subjected to treatment with elicitor or mechanical damages, it elaborates numerous inducible defense responses. Studies on the possibilities of similar defense response in their host by AM fungi reflected that it is neither completely negative nor positive. Host roots show little cellular responses to invasion by an AM fungi until arbuscule formation occurs in the cortical parenchyma. One of the most striking cytological modifications induced during resistance to pathogen attack is the formation by the host cell, appositions or papillae at the site of penetration attempts. It contains compounds like callose, phenolics, proteins or silicons, which are considered to contribute to wall reinforcement and resistance (Collinge et al. 1994). In case of AM, roots of most host plants show remarkably little reaction and no significant modification occur in the walls of epidermal

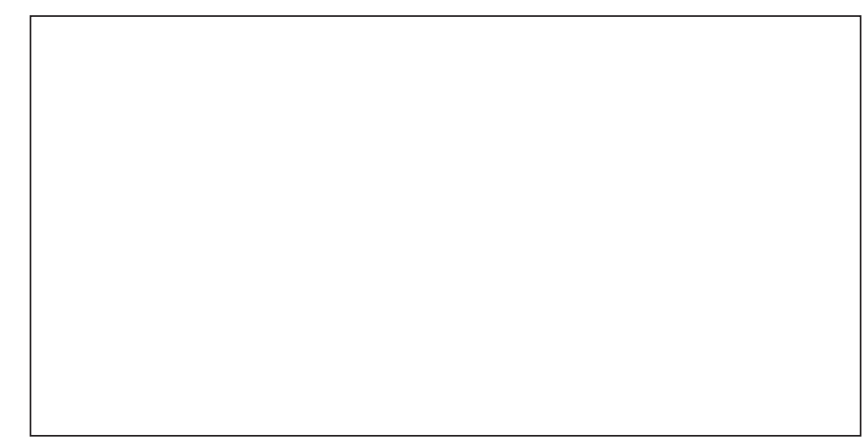

Fig. 7: The interaction of the Agrobacterium tumefaciens and its plant as a programmed series of signals and responses to those signals that are exchanged between the two organisms.

cells or hypodermal cells in contact with these first infection structures (Gianinazzi-Pearson et al. 1996b).

There is no evidence of the presence of phenolic in the walls or contents of these colonized cells, in contrast with what can be observed during infection of root cortex parenchyma by a fungal pathogen. Likewise, peroxidases, which are considered to be involved in cell wall reinforcement during pathogen interaction (Collinge et al. 1994) have not been found to be activated in cell containing arbuscules, although some increased activity has been detected on whole-root basis during mycorrhizal colonization (Gianinazzi and Gianinazzi-Pearson 1992).

Two cell wall defense-related molecules, namely b-1, 3glucans and hydroxyproline rich glycoprotein (HRGPs), were immunolocalized. The former was detected within the structural host wall material around the point of penetration of hyphae, but they disappeared along with the wall material as the fungus branched to form an arbuscule (GianinazziPearson 1995). HRGPs are located around arbuscule hyphae and reflect the elicitation of defense mechanism for limiting development of the symbiotic fungi within the host cell, but it might also be linked to the more general responses of cell wall building activity of the host membrane, since HRGPs are also extinsins (Showalter 1993). Cytological evidences reveal that significant plant cell wall alternation do not occur in root tissues during compatible interaction with AM fungi. It affects the assembly rather than the composition of wall components and consequently, they represent more a general plant responses to change in the cell environment rather than specific defense reactions.

\section{PATHOGENESIS-RELATED PROTEINS (PR PROTEINS)}

Pathogenesis-related proteins (PRs) are induced in plants in responses to pathogen infection (Carr and Klessig 1989; Stintzi et al. 1993). There are eleven families of pathogenesisrelated proteins (Van Loon 1994) designated as PR-11 and most are encoded by small gene families. Some PR proteins have known functions: PR-2, PR-3 and PR-11n proteins are hydrolytic enzymes with b-1, 3 glucanases are differentially expressed during mycorrhiza formation (Gianinazzi-Pearson et al. 1996a). In potato roots, there is an increase in the 
transcriptional activity as interaction initiates, followed by a strong repression of the expression genes. Corroborating observation of the suppression of chitinase and b-1, 3glucanase transcripts in the later stage of colonization in bean roots (Lambais and Mehdy 1993) and of the lack of corresponding immunologically detectable PR proteins in the root extracts of mycorrhizal tobacco.

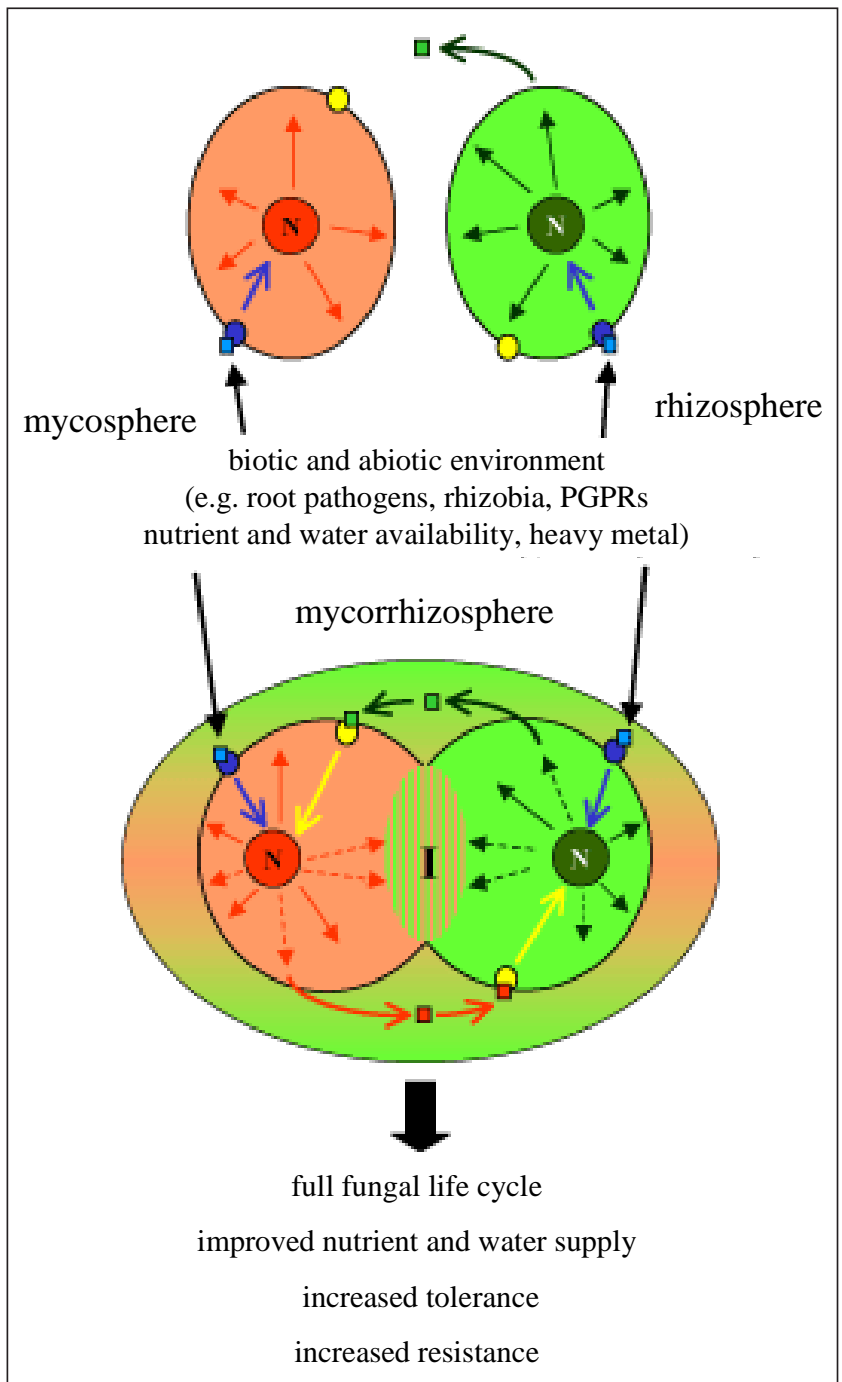

Fig. 8: Gene expression and regulation in AM partners: Signals (blue squares) from the environment (mycosphere and rhizosphere) interact with their corresponding receptors (blue circles) in AM fungi (red) and plant roots (green), initiate signal transduction chains (blue arrows) to the nuclei $(\mathrm{N})$ and finally regulate genes which results in expression patterns (red or green arrows) adjusted to the specific situation. When fungus and root are becoming close, a certain signal in the root exudates (green square) can interact with a specific receptor (yellow circle) in the AM fungus. This leads to the induction of a signal transduction chain (yellow arrow) and the expression of genes necessary for the first step of the interaction. One of these steps is the production of a fungal signal (red square) which is recognised by a plant receptor (yellow circle) also here resulting in a new gene expression profile. In the following, a circuit of signal-production, -perception and transduction leads to stage specific gene expression patterns (dashed arrows) in the fungus and the plant and step by step to the morphophysiological integration of the two partners in the arbuscular mycorrhiza and the formation of the interface (I). In the symbiosis, the fungus is able to fulfil its life cycle and the plant is better adapted to low nutrient concentrations, pathogens and abiotic stress in the mycorrhizosphere (c.f. Requena and Franken 2001).
The transient increase in the PR chitinase and b-1, 3-glucanse transcripts have been interpreted as an early defense responses by the plant to the invading mycorrhizal fungus, which is then repressed as symbiotic interactions develop. The overall weak expression of the PR-1 gene in AM, therefore, appears to result from very localized induction, rather than a general suppression of transcriptional activity (Gianinazzi-Pearson et al. 1996a).

\section{NON-HOST GENOTYPES DEFENSE RESPONSES}

The defense-related responses observed during compatible plant-fungal interactions in AM are different from the cytological changes and enhanced defense gene expression reported from the compatible plant-pathogen interaction (Gianinazzi-Pearson et al. 1996a). The latter appear to be similar to those in incompatible interaction, in that the defense mechanism is induced, but more slowly at later stages of the interactions. This pattern of plant-pathogen interaction differs from the spatio-temporal pattern associated with compatible interaction in AM, where defense responses are very limited, with an early transient activation phase followed by extremely localized, or repression of defense gene expression. This interpretation supposes that AM fungi can actively elicit plant defense, but that expression specifically modulated in host tissues. Control of defense responses should, therefore, be a key element in the establishment of high compatibility during biotrophic interactions between AM fungi and host roots (Gianinazzi-Pearson et al.1996a). Consequently, although the host plant must somehow limit fungal development on AM, the governing processes are likely to be different from those involved in pathogen control. Low priming of defense reaction by AM fungi does not appear to be due to the lack of essential fungal elicitor (s). The fungi are able to induce strong defense responses at the root surface of mycorrhiza resistant pea mutants $\left(\mathrm{myc}^{-}\right)$which is evidenced by the induced accumulation of defense- related molecules like phenolics, callose and PR-1 proteins in host cell wall apposition below appressoria. It has been proposed in mycorrhizal plants, specific host gene may play a regulatory role towards defense genes, s1 that their expression is suppressed or maintained at a low level (Table 3)

\section{AM SYMBIOSIS RELATED GENE}

Use of plant mutants show that the AM fungal morphogenesis is partly under the control of the host genome and may be stopped at different stages, and infection may proceed only when specific plant genes are functional. It was shown that specific plant genes are essential to AM establishment following the isolation of two mutants. In both the cases, resistance to AM fungi is found in plants which are unable to complete symbiotic interaction with Rhizobium. This indicates link between infection event in nodulation and AM formation early mutants are the most frequent; they are induced by atleast four mutated loci and properties of the mycorrhiza resistant character can be summarized as monogenic, recessive, genetically stable and indissociable from the nod character. When these mutants are allowed to infect with pathogenic fungi, it was observed that they are 
not able to confer any genes resistance to these pathogens (Nematode or Agrobacterium). These mutated genes appear to be symbiosis-specific, since they do not affect susceptibility to different pathogens. These genes are found to have a general spectrum of action, as their mutation affects at least two types of plant-microbe interaction nodules and mycorrhizae. This might explain why similar molecular components occur in the plant membrane during the two types of root infections. They are not affected by pathogenic interaction, which underlines the specificity.

\section{DIFFERENTIAL GENE EXPRESSION DURING MYCORRHIZATION}

Involvement of three different classes of genes are found during the infection process-first include the genes involved in the genesis of new cell components (membranes and cell wall) in those root cells colonized by intracellular hyphae and arbuscules; the second include genes involved in the metabolic functioning of mycorrhiza and third, the genes involved in some form of plant defense (Gianinazzi-Pearson et al. 1996a).

A model was proposed by Gianinazzi-Pearson (1995) to understand the molecular events involved between the symbiotic partners, according to which molecular interactions between both the partners are characterized by the production and perception of signals, resulting in the activation of a "cascade of genes", which guide the two partners from the first step of the recognition in the soil top the final development of a highly ordered structure. Signals are perceived either thorough a fungal cell surface or an intracellular receptor may get activated via a signal transduction pathway called "master gene". This will start a cascade induction of regulator and finally effector genes, so that the gene necessary for the infection of the plant cell are expressed, such as the certain structural and metabolic changes important for the symbiotic interaction, such as the arbuscules formation or synthesis of specific fungal enzymes involved in phosphate metabolism (Gianinazzi-Pearson and Smith 1993). This will result in morphological and physiological changes in AM fungi characterizing the symbiotic phase of their life cycle. Colonization includes an 'analogous cascade of events', leading to changes in the expression of certain host genes (Gianinazzi-Pearson 1995); such as the low expression of plant defense genes (Gianinazzi and Gianinazzi-Pearson 1992; Harrison and Dixon 1994), the enhancement of certain metabolic pathways and structural changes and the synthesis of novel proteins or polypeptides (Dumas-Gaudot et al. 1994). A new polypeptide of low molecular weight defined as "endomycorrhizin” was found which was absent in non-mycorrhizal control (Arines et al. 1993).

There are increasing number of reports showing that successful transformation of plants to constitutively express high level of defense related genes is accompanied by an increase in their resistance to root fungal pathogens. In order to know whether such enhanced gene could also affect root colonization by symbiotic fungi, a number of transgenic species of Nicotiana spp have been tested for their ability to develop AM.

Bi-directional nutrient transfer between the plant and the fungus is a key feature of arbuscular mycorrhizal symbiosis. The major nutrients exchanged between the symbiotic partners are reduced carbon, assimilated through the plant photosynthesis and phosphate, taken up by the fungal hyphae exploring soil microhabitats. This nutrient exchange takes place across the symbiotic interface, which are bordered by the plant and fungal plasma membranes (Ferrol et al. 2002). Uptake of nutrients into the root symplasm occurs through transporter proteins embedded in this membrane. These transporters belong to a family of membrane proteins characterized by having 12 membrane-spanning domains arranged in a ' $6+6$ ' configuration. $\mathrm{H}_{2} \mathrm{PO}_{4}$ - ions, together with

Table 3: Some Plant Resistance Marker Molecules Investigated in Fungus-Root Interaction in Arbuscular Mycorrhiza (c.f. GianinazziPearson et al. 1996a).

\begin{tabular}{|c|c|c|}
\hline Molecules & Modification & References \\
\hline Phytoalexins & $\begin{array}{l}\text { Late or transient increase in some flavonoids PAL, } \\
\text { CHS, and CHI transcripts during root colonization. } \\
\text { Localization of PAL and CHS transcripts in arbuscular } \\
\text { containing cells. No increase in IFR transcripts }\end{array}$ & $\begin{array}{l}\text { Morandi et al.1984; Harrison and Dixon } \\
\text { 1993, } 1994 .\end{array}$ \\
\hline Callose & $\begin{array}{l}\beta-1,3 \text { glucans in host wall at the base of arbuscule } \\
\text { trunks }\end{array}$ & $\begin{array}{l}\text { Gollotte et al.1995; Gianinazzi-Pearson } \\
1995 .\end{array}$ \\
\hline Peroxidase & $\begin{array}{l}\text { Increase in total and wall bound activity in early stage } \\
\text { of colonization. No localization in arbuscular } \\
\text { containing cells }\end{array}$ & $\begin{array}{l}\text { Spanu and Bonfante- Fasolo 1988; } \\
\text { Gianninazzi and Gianninazzi-Pearson 1992; } \\
\text { Mc Arthur and Knowles 1992. }\end{array}$ \\
\hline Chitinase & $\begin{array}{l}\text { Early increase in transcripts and activity, generally } \\
\text { followed by suppression in later stage of } \\
\text { colonization. New isoforms }\end{array}$ & $\begin{array}{l}\text { Spanu et al. 1989; Volpin et al.1994; } \\
\text { Lambais and Mehdy 1993; Dumas } \\
\text { Gaudot et al. 1992ab, 1994a. }\end{array}$ \\
\hline$\beta-1,3$ glucanase & $\begin{array}{l}\text { No detectable quantitative changes in } \\
\text { protein and decrease in transcripts in later stage of } \\
\text { colonization }\end{array}$ & $\begin{array}{l}\text { Dumas et al.1989; Lambais and Mehdy } \\
1993 .\end{array}$ \\
\hline PR-1 protein & $\begin{array}{l}\text { Slight increase in transcripts. Localization around } \\
\text { living arbuscules }\end{array}$ & Gianinazzi-Pearson et al. 1992. \\
\hline
\end{tabular}




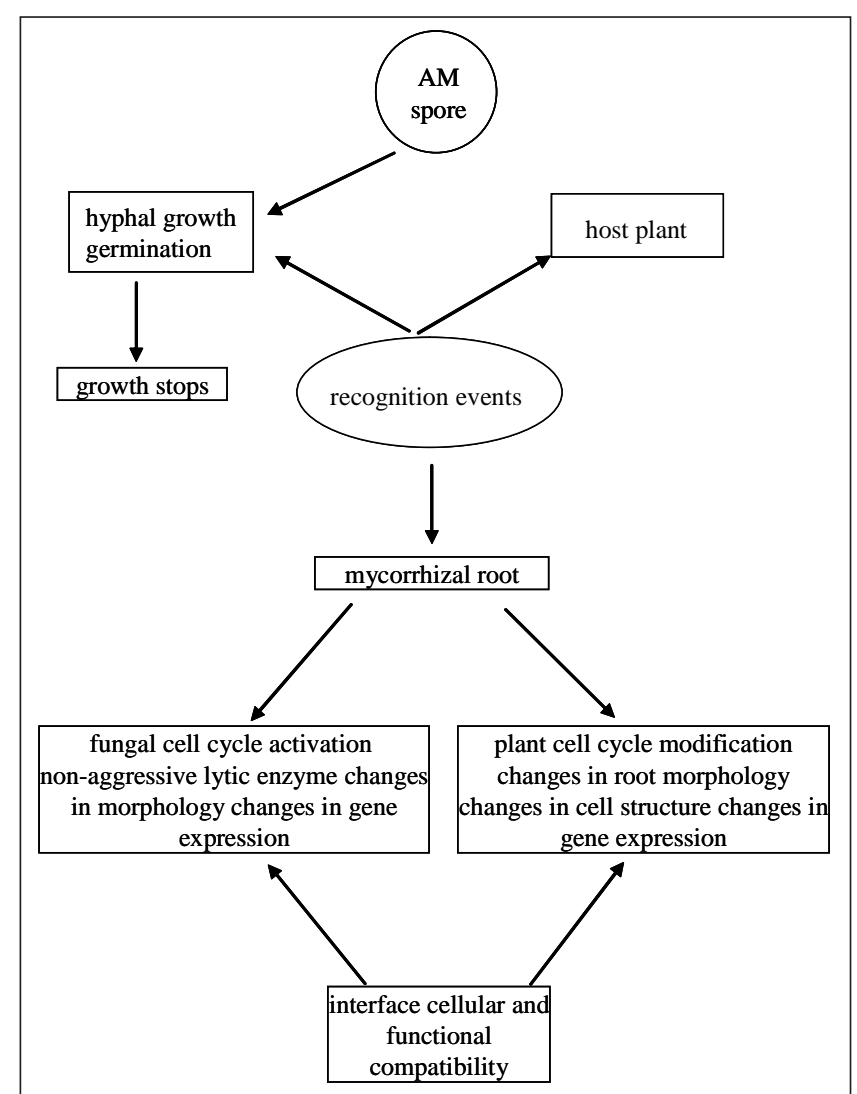

Fig. 9: The flow chart summarizes some of the check points which control the establishment of AM symbiosis (c.f. Bonfante- Fasolo and Perotto 1995).

protons are transported through this protein (Smith 2002). This transport process is driven by the potential across the membrane maintained by the action of $\mathrm{H}^{+}$-ATPase, the 'proton pump', that extrudes proton to the outer surface of the membrane. The expression of genes encoding high affinity root phosphate transporter is regulated by the phosphorous (P) status of the plant. Under phosphate stress, the expression of genes encoding these transporters is up regulated. This result in a greater number of transporter proteins in the plasmalemma and enhanced phosphate uptake rates, if phosphate is available at the membrane surface. Uptake occurs around the root tip, into the epidermal cells with their associated root hairs and into cells in the outer layers of the root cortex.

Vierheilig et al. (1993) first reported that, although roots of transgenic plants of Nicotiana sylvestris constitutively express tobacco, a defense related protein, they were more resistant to $R$. solani, where they were colonized by $G$. mosseae, resistance conferred was found to be similar to that in plant transformed with an empty vector. Reason behind this is most probably because of the vacuolar origin of chitinase activity and hyphae always avoid vacuoles, while entering intracellularly in to the root cortical cells. Comparable observations have been seen in transformed Nicotiana tabacum, highly expressing genes enfolding various PR proteons. Moreover, amphi-diploid hyphae between Nicotiana glutinosa and Nicotiana debneyi, which constitutively express a number of PR genes, are highly resistant to pathogens (Ahlgoy et al.1992) is susceptible tom
AM fungus as is the parent species. Consequently enhanced resistance to pathogen conferred by the constitutive expression of defense related genes do not interfere with the symbiotic potential of plants. The reason for this is not clear. (Fig. 9).

Burleigh and Harrison (1997) have reported a novel gene (Mt 4), whose expression in Medicago truncatula roots is suppressed in response to colonization by AM fungi and phosphate nutrition. A cDNA clone (Mt 4) was isolated as a result of a differential screen to identify genes showing altered expression during the interaction between Medicago truncatula and vesicular-arbuscular mycorrhizal fungus, $G$. versiforme. Mt 4 represent a Medicago truncatula RNA that contains numerous short open reading frames, the two longest of which are predicted to encode polypeptide of 51 amino acid each. One of these open-reading frames shares a short region of identity with a phosphate starvation-inducible gene from tomato. It has been observed that expression of this is regulated in response to colonization: transcripts were detected in nonmycorrhizal roots and level decreased in both M. trancatula and M. sativa roots after colonization between G. versiforme. Transcript level also decreased during the incompatible interaction between $G$. versiforme and a $M$. sativa mycorrhizal minus (myc-) line indicating that the downregulation of this course early during the interaction between the fungus and its host plant. Phosphate levels in the nutrient media also affected the expression of the Mt 4 gene: transcripts were present in the roots of plant grown under phosphate deficient conditions, but undetectable in the plant roots grown under phosphate sufficient condition. Mt 4 gene is the first gene to be identified whose expression is altered independently by both mycorrhizal colonization and phosphate nutrition and as such, it may provide a starting point from which to analyze the signal transduction pathway involved in phosphate nutrition and mycorrhizal symbiosis. While the function of the peptide(s) encoded by the Mt 4 gene are currently unknown, a precedent has been set up for the importance of small peptides in plant growth response, and it is tempting to speculate that Mt 4 may also encode a biologically active peptide involved in some aspects of phosphate nutrition.

\section{RECENT DISCOVERIES}

A novel plant promotional root colonizing fungus, Piriformospora indica Verma et al. has been isolated from a desert soils in northwestern part of India (Verma et al. 1998). The fungus was able to grow axenically on a variety of simple and complex media. Electron microscopy and genomic studies employing the analysis of a part of 18S and 28S rRNA placed it in Hymenomycetes (Basidiomycota) (Verma et al. 1998, Varma et al. 1999). Sebacina vermifera sensu (Warcup and Talbot) which was isolated from Bavaria, South Germany (Warcup and Talbot 1967; Weiß and Oberwinkler 2001) also occupied the same taxonomic position as that for P. indica. Based on 28S and internal transcribed spacer (ITS) data, Neottia nidus-avis, was found to be closely related P. indica and S. vermifera sensu (McKendrick et al. 2003). 
$P$. indica, mimics most of the beneficial characteristics of arbuscular mycorrhizal fungi (AMF). The fungus displays immense potential for fundamental molecular studies on symbiotic interactions.

$P$. indica colonizes the roots of a diverse range of host plants including legumes, cereals, medicinal plants and some bryophytes asymtomatically, and forms a mycorrhiza with terrestrial orchids (Blechert et al. 1999; Singh et al. 2003a,b; Varma et al. 1999). These properties are normally reported for arbuscular mycorrhizal fungi.

Geosiphon pyriforme ( Kutz) v. Wettstein is a coenocytic soil fungus and until now the only known example of a fungus living in endocytobiotic association with a cynobacterium, i.e. with Nostoc punctiforme (Fig. 10) . On the basis of analysis and comparing nearly complete small subunit ribosomal RNA genes of Geosiphon pyriforme and Glomus versiforme, it was obtained that Glomales tree include

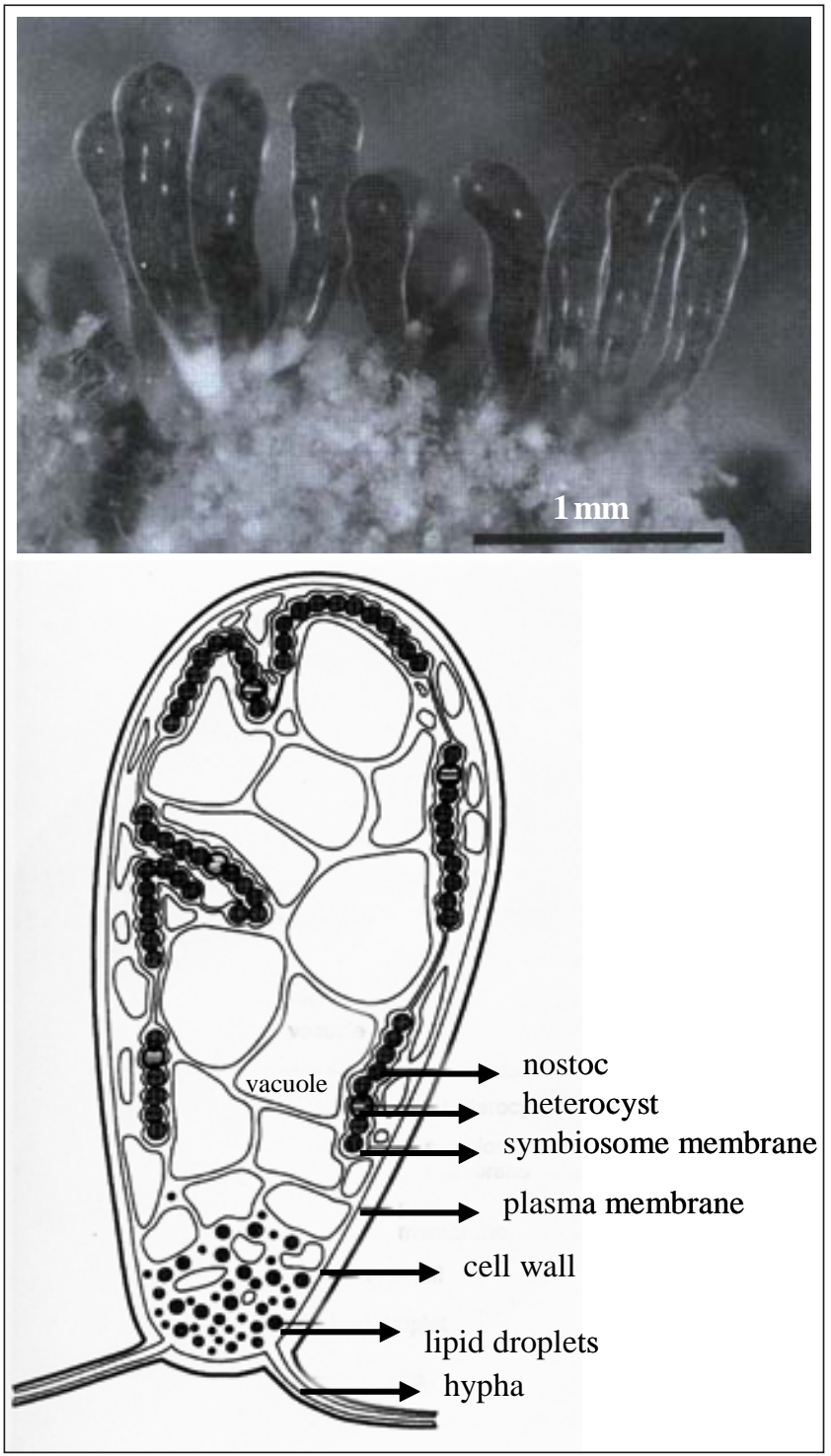

Fig. 10: Geosiphon pyriforme, an endocytosymbiosis between fungus and cyanobacterium- a model system for arbuscular mycorrhizal research. A. Geosiphon bladders, harvested from laboratory culture on natural substrate B. Schematic drawing of Geosiphon bladder compartmentation (c.f. Schuessler and Kluge 2001).
Geosiphon and form a distinct branch not clustering with any other group of the Zygomycetes sequenced so far (Schuessler and Kluge 2001). As far as Geosiphon is concerned, it is now clear that the fungus represents a probably ancestral member of the Glomales, and recent sequence analysis show that it is very closely related to the dimorphic AMF Acaulospora gerdemannii.

\section{MODEL INTERACTION}

Arabidopsis thaliana seedlings show extensive root proliferation and root branching, when they are co-cultivated with $P$. indica. Changes in the morphology and the protein pattern of the inoculated roots can be observed before the physical contact between the partners occur. In addition, inoculated roots exert an intensive auto-fluorescence, similar to the one observed in dormant spores when fungus is grown independently. Longer incubation with the fungus results in the root colonization and overall promotion of the plant growth (Fig. 11).

\section{HYPOTHESIS OF INTERACTION}

Basic mechanism involved in the plant-microbe symbiosis especially with respect to mycorrhizal fungi is not well understood. The bottleneck is that the arbuscular mycorrhizal fungi are obligate symbionts and cannot be grown axenically. RT-PCR has shown that $P$ indica infection of $A$. thaliana roots leads to the induction of two plasma membrane kinases of the LRR family. Approximately 150 genes in Arabidopsis, are recorded very little is known about their function. They perceive signals from the outside of the cell and transduce them further into the cell, normally for gene expression. Signal pathways do not exist in mammals and yeast.

One up-regulated gene is $\mathbf{X 9 7 7 7 4 - ~ T h e r e ~ i s ~ o n l y ~ o n e ~}$ homologue in Databanks. It is from Medicago truncatula. A mutant in this gene cannot form nodules. The gene product functions as receptor for the bacterial "nod ling factor". There are two knock out lines available for Arabidopsis. One can check whether these mutants fail to interact with $P$ indica.

Second gene is $\mathbf{1 8 4 0 1 6 6 2 -}$ It is up regulated at the mRNA level. This protein is quite abundant in plasma membrane preparation from A. thaliana roots. It is interesting to check, whether there is more of this protein after fungal infection in approximately 7 weeks. To authors surprise, nobody has looked at this gene/protein yet, although there are 10 knock out lines available in Arabidopsis. To our knowledge this is also the first time that a new gene was identified at the mRNA level and the protein level simultaneously.

\section{FUTURE PERSPECTIVES}

It is relevant to optimise the physiological conditions for the varied interactions and describe the molecular mechanism (s) which regulates the recognition of the symbiotic partners and growth promotion. The important issues which warrant urgent intervention are: 


\section{Optimizing physiological conditions to understand the mechanism of interaction}

Ingredients of the fungal media play significant role in the interaction. This aspect needs to be optimised. The plan of work should be further focussed on:

- The complete root colonization pattern of the root system

- The very first step of contact between the fungus and the host which takes place at the root hair zone

- The preferential colonization sites on the root surface, which are grooved along the junctions of the epidermal cells

- Specific infection structures such as appressoria

- Use of GFP (Green Fluorescence Protein) as a marker for $P$. indica-an effective approach for studying plant-fungus interactions.

2. Identification of the plant proteins involved in the recognition events and the phytopromotion

Identification of the symbiosis-specific proteins which are responsible for the early phase of interaction (pre-symbiotic phase) and identification of the corresponding genes

- Temporal and spatial expression of identified genes and proteins

- Inactivation of the genes in vivo and/or use of the available $A$. thaliana mutants in order to understand the protein function

- Identification of other components of the protein complexes involved in the recognition events

\section{Identification and the specific function of the autofluorescent compound}

Chemical nature of the fluorescent compound (s) in the dormant spore

- Significance for the reduction of the fluorescence during the spore germination and the hyphae

- Chemical nature of the fluorescent compound (s) in the root hairs

- Purpose and physiological significance of the enhanced auto-fluorescence in the root hairs as a result of the interaction with $P$. indica.

4. Characterization of the signals involved with inhibition and promotion of rhizobacteria and $P$. indica

Nature of compound (s) produced by strains of Pseudomonas, Bacillus and Actinomycetes blocking the growth of fungal growth and sporulation

- Mechanism involved for the inhibitory reactions

- Signals involved for the uniform promotion of the positive interaction of P. indica with nitrogen -fixing bacteria

- Characterization of bio-molecules involved with promotion of spores and over all growth.

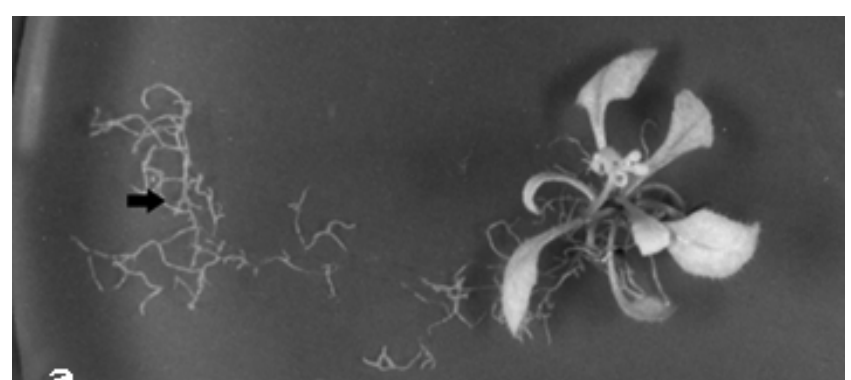

a

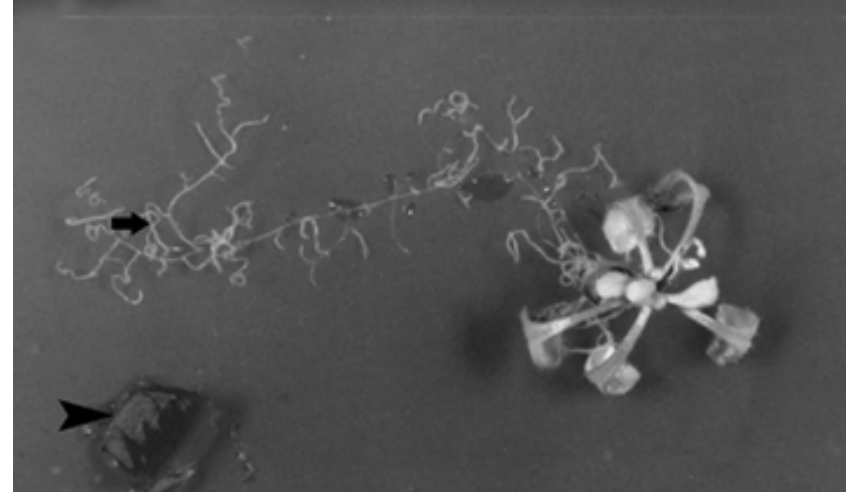

b

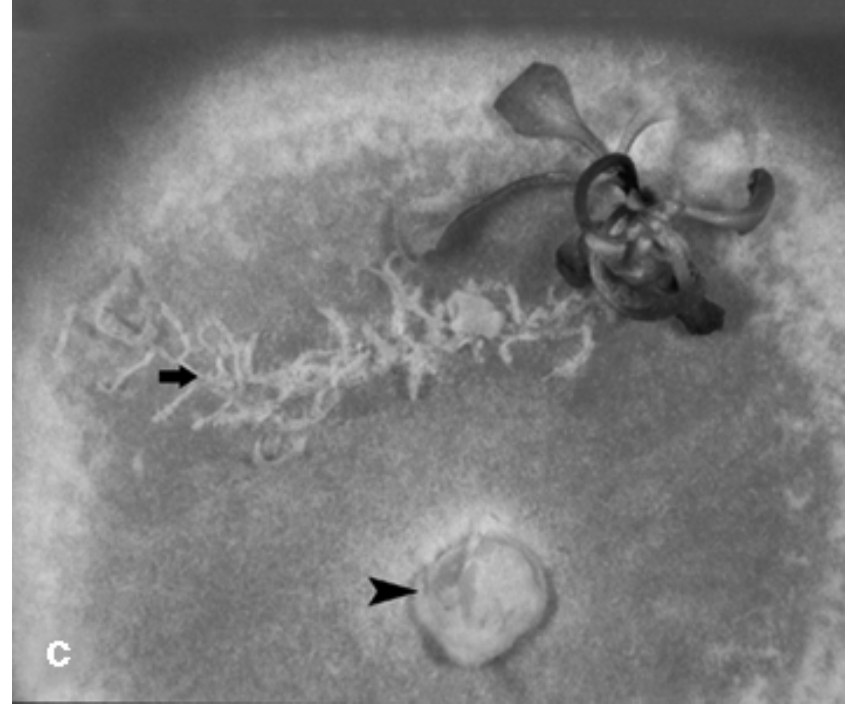

Fig. 11: Differences in A. thaliana plant pigmentation as a result of fungal colonization after 7 days of growth. (a) control- plant alone, (b) plant co-culture with Pisolithus tinctorius, (c) plant co-culture with $P$. indica. Black arrowhead show $(\rightarrow)$ the root proliferation and arrow (>) show the placement of the fungal inoculum.

\section{ACKNOWLEDGEMENT}

The author is grateful for the suggestions and help offered by Ajit Varma, India, Ralf Oelmueller, Germany and Puja Sharma, India. Further extends her thanks to the Faculty Development Board and Central Department of Microbiology, Tribhuvan University, Nepal.

\section{REFERENCES}

Ahlgoy, P., Felix,G., Metraux, J.P. and Meinz, Jr.F. 1992. Resistance to disease in the hybrid Nicotiana glutinosa $x$ Nicotiana debneyi is associated with high constitutive levels of â-1, 3-glucanase, chitinase, peroxidase and polyphenoloxidase. Physiological and molecular plant pathology. 41:11-21. 
Alexander, T., Toth, R., Meier, R. and Weber, H.C. 1989. Dynamics of arbuscules development and degeneration in onion, bean and tomato with reference to vesicular-arbuscular mycorrhizas in grasses. Can. J. of Bot. 67:2505-2513.

Allen, E.B., Chambers, J.C., Conner, K.F., Allen, M.F. and Brown, R.W. 1987. Natural establishment of mycorrhiza in disturbed alpine ecosystem. Alp. Res. 19:11-20.

Arines, J., Palma, J.M. and Vilarino, A. 1993. Comparison of protein patterns in non-mycorrhizal and vesicular-arbuscular mycorrhizal roots of red clover. New Phytol. 123:763-768.

Azcon-Aguilar, C. and Barea, J.M. 1992. Interaction between mycorrhizal fungi and other rhizosphere microorganisms. In: mycorrhizal functioning: An integrate plant-fungal process (ed.) MF Allen. Chapman and Hall, New York, pp. 163-198.

Azcon-Aguilar, C. and Barea, J.M. 1996. Arbuscular mycorrhizas and biological control of soil-borne plant pathogen-an overview of the mechanism involved. Mycorrhiza. 6:457-464.

Balaji, B., Paulin, M.J., Vierheilig, H. and Piché, Y. 1995. Responses of an arbuscular mycorrhizal fungus, Gigaspora margarita, to exudates and volatiles from Ri T-DNA-transformed roots of nonmycorrhizal and mycorrhizal mutants of Pisum sativum L. Sparkle. Exp. Mycol. 19: 275-283.

Barea, J.M., Andrade, G., Bianciotto, V., Dowling, D.N., Lohrke, S., Bonfante, P., Gara, F.O. and Azcon-Aguilar, C. 1998. Impact on arbuscular mycorrhiza formation of Pseudomonas strains used as inoculants for the biocontrol of soil-borne plant fungal pathogens. Appl. Environ. Microbiol. 64: 2304-2307.

Barea, J.M., Azcon, R. and Azcon-Aguilar, C. 1993. Mycorrhiza and crops. Adv. Plant Path. 9:167-189.

Becard, G., Taylor, L.P., Douds, D.D., Pferrer, P.E. and Doner, L.W. 1995. Flavonoids are not necessary plant signals in arbuscular mycorrhizal symbiosis. Molecular Plant Microbe Interactions. 8:252-258.

Becard, G. and Piché, Y. 1992. Establishment of VA mycorrhizae in root organ culture: Review and proposed methodology. In: Methods in Microbiology. JR Norris, DG Read and AK Varma (eds.), Academic Press, London. 24:89-108.

Becard, G. and Piché, Y. 1989. New aspects on the acquisition of biotropic status by a vesicular-arbuscular mycorrhizal fungus Gigaspora margarita. New Phytol. 112:77-83.

Blechert, O., Kost, G., Hassel, A., Rexer, K.H. and Varma, A. 1999. First remarks on the symbiotic interaction between Piriformospora indica and terrestrial orchids. In: Mycorrhiza: Structure, Function, Molecular biology and Biotechnology. A Varma and B Hock (eds.), $2^{\text {nd }}$ edn, Springer-Verlag, Germany. pp. 683-688.

Berta, G., Sgorbati, S., Soler, V., Fusconi, A., Trotta, A., Citterio, A., Bottone, M.G., Sparvoli, E. and Scannerini, S. 1990. Variation in chromatin structure in host nuclei of a vesicular-arbuscular mycorrhiza. New Phytol. 14:199-205.

Bianciotto, V., Minerdi, D., Perotto, S. and Bonfante, P. 1996. Cellular interactions between arbuscular mycorrhizal fungi and rhizosphere bacteria. Protoplasma. 193:123-131.

Bianciotto, V., Palazzo, D. and Bonafante, P. 1989. Germination process and hyphal growth of a vesicular-arbuscular mycorrhizal fungus. Allionia. 29:17-24.

Bianciotto, V. and Bonfante, P. 1998. Presymbiotic versus symbiotic phase in arbuscular endomycorrhizal fungi. In: Mycorrhiza. A Varma and B Hock (eds.), $2^{\text {nd }}$ edition, Springer. pp. 229-251.

Bonfante, P. and Perotto, S. 1992. Plant and endomycorrhizal fungi: The cellular and molecular basis of their interaction. In: Molecular Signal in plant Microbe Communication, DPS Verma (ed.) Boca Raton, CRC Press. pp. 445-470.
Bonfante-Fasolo, P. and Scannerini, P. 1992. The cellular basis of plant-fungus interchanges in mycorrhizal associations. In: Functioning in Mycorrhizal. M Allen (ed.) Academic Press, San Diego, pp. 65-101.

Bonfante-Fasolo, P. and Perotto, S. 1990. Mycorrhizal and pathogenic fungi; do they share any features? In Electron microscopy of plant pathogens. K Mengden and DE Lessemann (eds.), SpringerVerlag, Germany. pp. 265-275

Bonfante-Fasolo, P., Tamagnone, L., Perotto, R., Esquerre-Tugaye, M.T., Mazau, D., Mosiniak, M. and Vian, B. 1991. Immunocytochemical location of hydroxyproline-rich glycoprotein at the interface between a mycorrhizal fungus and its host plants. Protoplasma. 165: 127-138.

Brewin, N.J. 1990. The role of the plant plasma membrane in the symbiosis. In: The Plant Plasma Membrane. C Larsson and M Moller (eds.), Berlin, Springer-Verlag, pp. 351-375.

Brundrett, M.G. and Kendrick, B. 1990. The roots and mycorrhizas of herbaceous woodland plants, $H$ : Structural aspect morphology. New Phytol. 114: 469-479.

Burleigh, S. and Harrison, M.J. 1997. A novel gene whose expression in Medicago truncatula roots is suppressed in response to colonization by vesicular-arbuscular mycorrhizal (VAM) fungi and to phosphate nutrition. Plant Mol. Bio. 34:199-208.

Burggraff, A.J.P. and Beringer, J.E. 1989. Absence of nuclear DNA synthesis in vesicular arbuscular mycorrhizal fungi during in vitro development. New Phytol. 111:25-33.

Carr, J.P. and Klessig, D.F. 1989. The pathogenesis-related proteins in plants. In: Genetic engineering: Principles and methods, JK Setloe (ed.), Plenum Press, New York. 65-109.

Cheon, C., Lee, N.G., Siddque, A.B.M., Bal, A.K. and Verma, D.P.S. 1993. Role of plant homologous of Rab1p and Rab7p in the biogenesis of peribacteroid membrane, a subcellular compartment formed de novo during root nodule symbiosis. The EMBO J. 11:4125-4135.

Collinge, D.B., Gregersen, P.L. and Thordal-Christensen, H. 1994. The induction of gene expression in response to pathogenic microbes. In: Mechanisms of plant growth and improved productivity: Modern approaches and perspectives. AS Basra and M Dekker (eds.), Plenum Press, New York. pp. 391-433.

Denison, R.D., Bledsoe, C., Kahn, M., Gara, F.O., Simms, E.L. and Thomashow, L.S. 2003. Ecology. The Ecological Society of America. 84:838-845.

Dumas-Gaudot, E., Tahiri-Alaoui, A., Gianinazzi-Pearson, V. and Gianinazzi, S. 1994. Changes in polypeptide patterns in tobacco roots colonized by two Glomus species. Mycorrhiza. 4:215-221.

Ferrol, N., Barea, J.M. and Azcon-Aguilar, C. 2002. Mechanism of nutrient transport across interfaces in arbuscular mycorrhizas. Plant and Soil. 244:231-237

Gianinazzi, S. and Gianinazzi-Pearson, V. 1992. Cytology, histochemistry and immunocytochemistry as tools for studying structure and function in endomycorrhiza. In: Methods in microbiology 24D. JR Norris, DJ Read and AK Varma (eds.), Academic Press, London. pp. 109-139.

Gianinazzi, S. and Gianinazzi-Pearson, V., Franken, P., Dumas-Gaudot, V., Tuinen, D.V., Samra, A., Martin-Laurent, F. and Dassi, B. 1995. Molecules and genes involved in mycorrhiza functioning. In: Biotechnology of Ectomycorrhizae. V Stocchi (ed.), Plenum Press, New York. pp. 67-76.

Gianinazzi-Pearson, V., Gollotte, A., Cordier, C. and Gianinazzi, S. 1996a. Root defense response in relation to cell and tissue invasion by symbiotic microorganism: cytological investigation. In: Histology, ultrastructure and molecular cytology of plant. 
Microorganism interaction. M Nicole and V Gianinazzi-Pearson (eds.), Dordrecht. Kluwer Academic Publishers. pp. 177-191.

Gianinazzi-Pearson, V., Tahiri-Alaoui, A., Antoniw, J.F., Gianinazzi, S. and Dumas, E. 1992. Weak expression of the pathogenesisrelated $P R-b 1$ gene and localization of related protein during symbiotic endomycorrhizal interactions in tobacco roots. Endocytobiosis and cell research. 8:177-185.

Gianinazzi-Pearson, V., Dumas-Gaudot, E., Gollotte, A., Tahiri-Alaoui, A. and Gianinazzi, S. 1996b. Cellular and molecular defenserelated root responses to invasion by arbuscular mycorrhizal fungi. New Phytol. 133:45-57.

Gianinazzi-Pearson, V., Dumas-Gaudot, E., Gianinazzi, S. 1998. Proteins and protein activities in endomycorrhizal symbiosis. In: Mycorrhiza, 2nd edition. A Varma and B Hock (eds.) SpringerVerlag, Berlin. pp. 255-272.

Gianinazzi-Pearson, V. and Smith, S.E. 1993. Physiology of mycorrhizal mycelia. In: Mycorrhiza synthesis; Advances in plant pathology. DS Ingram, PH Williams and IC Tommerup (eds.), Academic Press, London. pp. 52-82.

Gianinazzi-Pearson, V. 1995. Morphofunctional compatibility in interactions between roots and arbuscular mycorrhizal fungi: molecular mechanisms, genes and genes expression. In: Diseases. K Kohmoto, RP Singh and US Singh (eds.), Peragmon Press, Elsevier Science, Oxford. 2:251-263.

Giovannetti, M., Avio, L., Sabrana, C. and Citernesi, A.S. 1993. Factors affecting appressorium development in the VAM fungus Glomus mosseae (Nicol and Gerd) Gerd and Trappe. New Phytol. 123:114122.

Giovannetti, M., Sbrana, C., Citernesi, A.S. and Avio, L. 1996. Analysis of factors involved in fungal recognition responses to host-derived signals by arbuscular mycorrhizal fungi. New Phytol. 133:65-71.

Gollotte, A., Lemoine, M.C. and Gianinazzi-Pearson, V. 1996a. Morphofunctional integration and cellular compatibility between endomycorrhizal symbionts. In: Concepts in mycorrhizal research: Handbook of vegetation science series. K Mukerji (ed.), Kluwer Academic Publishers, Netherlands. pp. 91-111.

Gollotte, M., Sbrana, C., Citernesi, A.S. and Avio, L. 1996b. Analysis of factors involved in fungal recognition responses to host-derived signals by arbuscular mycorrhizal fungi. New Phytol. 133:65-71.

Harrison, M. and Dixon, R.A. 1994. Spatial patterns of expression of flavonoids/isoflavonoids pathway genes during interaction between roots of Medicago truncatula and the mycorrhizal fungus Glomus versiforme. The Plant J. 6:9-20.

Hirsch, A.M. and Kapulnik, Y. 1998. Signal transduction pathways in mycorrhizal associations: symbiosis. Fungal Genet. Biol. 23:205-212.

Howard, R.J. and Ferrari, M.A. 1989. Role of melanin in appressorium function. Experimental Mycology. 13:403-418.

Janos, D.P. 1987. VA Mycorrhizas in humid tropical ecosystem. In: Ecophysiology of VA mycorrhizal plants. GR Safir (ed.), CRC, Boca Raton. pp. 107-134.

Johnson, N.C. and Pfleger, F.L. 1992. Vesicular-arbuscular mycorrhizae and cultural stresses. In: Mycorrhiza in Sustainable Agriculture. GJ Bethlenfalvay and R.G. Lindermann (eds.), ASA special publication, Madison, Wisconsin, USA. pp. 71-79.

Kobayashi, I. and Kunoh, Y. 1992. Recognition of a pathogen and non-pathogen by barley coleoptile cells III. Responses of microtubules and actin filaments in barley coleoptile cells to penetration attetration attempts. Can. J. of Bot. 70:1815-1823.

Koske, R.E. and Gemma, J.N. 1992. Fungal reaction to plant prior to mycorrhizal formation. In: Mycorrhizal Functioning: An Integrative Plant-Fungal Process. FM Allen. (ed.), pp. 3-36.
Leake, J.R. 1994. The biology of myco-hetrotrophic (saprophytic) plants. New Phytol. 127:171-216.

Lambais, M.R. and Mehdy, M.C. 1993. Suppression of endochitinase, B1, 3-endoglucanase and chalcone isomerase expression in bean vesicular-arbuscular mycorrhizal roots under different soil phosphate conditions. Molecular Plant-Microbe Interaction. 6:75-83.

Lindermann, R.G. 1992. Vesicular-arbuscular mycorrhizae and soil microbial interactions. In: Mycorrhizae in Sustainable Agriculture. GJ Bethlenfalvay and RG Lindermann (eds.), ASA special publication, Madison, Wisconsin. pp. 45-70.

Lynn, D.G. and Chang, M. 1990. Phenolic signals in combination: implications for plant development. Annual Review of Plant Physiology and Plant Molecular Biology. 41:497-526.

Matsuhashi, M., Pankrushina, A.N., Endoh, K. 1996a. Bacillus carboniphilus cells respond to growth-promoting physical signals from cells of homologous bacteria. J. Gen. and Appl. Microbiol. 42:315-323.

McKendrick, S.L., Leake, J.R., Taylor, D. Lee and Reed, D.J. 2003. Symbiotic germination and development of the mycoheterotrophic orchid Neottia nidus-avis in nature and its requirement for locally distributed Sebacina spp. New Phytol. 154:233-247.

Millar, R.M. and Jastrow, J.D. 1992a. The application of VA mycorrhizae to ecosystem restoration and reclamation. In: Mycorrhizal Functioning: An Integrative Plant Fungal Process. MF Allen (ed.), Chapman and Hall, New York, pp.438-467.

Millar, R.M. and Jastrow, J.D. 1992b. The role of mycorrhizal fungi in soil conservation. In: Mycorrhiza in Sustainable Agriculture. GJ Bethlenfalvay and RG Lindermann (eds.), ASA special publication, Madison, Wisconsin, USA. pp.29-44.

Morton, J.B. and Benny, G.L. 1990. Revised classification of arbuscular mycorrhizal fungi (Zygomycetes): a new order, Glomales, two new suborders, Glomineae and Gigasporineae, and two new families, Acaulosporaceae and Gigasporaceae, with an emendation of Glomaceae. Mycotaxon. 37:471-491.

Morton, J.B. and Redecker, D. 2001. Two new families of Glomales, Archaeosporaceae and Paraglomaceae with two new genera Archaeospora and Paraglomus based on concordant molecular and morphological characters. Mycologia. 93:181-195.

Nadkarni, N.M. 1985. Roots that go out on a limb. Nat. Hist. 94:42-48.

Nagahashi, G., Abney, G. and Doner, L.W. 1996. A Comparative study of phenolic acids associated with cell walls and cytoplasmic extracts of host and non-host roots for AM fungi. New Phytol. 133:281-288.

Nair, M.G., Safir, G.R. and Siqueira, J.O. 1991. Isolation and identification of vesicular-arbuscular mycorrhiza-stimulatory compounds from clover (Trifolium repens) roots. Appl. Environ. Microbiol. 57:434-439.

Neeraj, A., Shandkar, Mathew, J. and Varma, A.K. 1991. Occurrence of VA mycorrhizae within Indian semi-arid soils. Biol. and Fertile. of Soils. 11:140-144.

Perotto, S. and Bonfante, P. 1997. Bacteria associations with mycorrhizal fungi: close and distant friends in the rhizosphere. Trends Microbiol. 5:496-501.

Peters, N.K. and Verma, D.P.S. 1990. Phenolic compounds as regulators of gene expression in plant-microbe interactions. Mol. Plant Microbe Interact. 3:4-8.

Requena, N. and Franken, P. 2001. Analysis of gene expression in arbuscular mycorrhizas: new approaches and challenges. Research Review, New Phytol. 150:517-523.

Rovira, A.D. 1996. Plant root exudates. Botanical Reviews. 35:35-58. 
Sarmantry, S., Rout, G.R. and Das, P. 1998a. Differential nickel tolerance of mung bean ( Vigna radiata L.) genotype in nutrient culture. Agronimie. 18:537-544.

Sarmantry, S., Rout, G.R. and Das, P. 1998b. Role of chromium on plant growth and metabolism. Acta Physiol. Plantarum. 20:201-212.

Schuessler, A. and Kluge, M. 2001. Geosiphon pyriforme, an endocytosymbiosis between fungus and cynobacteria, and its meaning as a model system for arbuscular mycorrhizal research. In: The Mycota IX. B Hock (ed.), Springer-Verlag, Germany. pp. 151-161.

Showalter, A.M. 1993. Structural and function of plant cell wall proteins. The Plant Cell. 5:9-23.

Singh, An., Singh, Ar., Rexer, K-H, Gerhards, K. and Varma, A. 2001. Root endosymbiont: Piriformospora indica - A Boon for Orchids. J. of Orchid Society of India. 15:89-102.

Singh, An., Singh, Ar., Kumari, M., Rai, M.K. and Varma, A. 2003a. Biotechnology importance of Piriformospora indica-A novel symbiotic mycorrhiza-like Fungus: An Overview. Plant Biotechnology- the Special Issue. Indian J. of Biotech. 2:65-75.

Singh, An., Singh, Ar., Kumari, M., Kumar, S., Rai, M.K., Sharma, A.P and Varma, A. 2003b. AMF-like-fungus: Piriformospora indica a boon for plant industry. In: BN Prasad (ed.), Biotechnology in Sustainable Biodiversity and Food Security. Science Publishers Inc., Enfield, New Hampshire, USA. pp. 101-124.

Siqueira, J.O., Nair, M.G., Hammerschmidt, R. and Safir, G.R. 1991. Significance of phenolic compounds in plant-soil-microbila system. Crit. Rev. Plant Sci. 10:63-121.

Smith, F.W. 2002. The phosphate uptake mechanism. Plant and Soil. 245:105-114.

Smith, S. and Smith, F. 1990. Structure and function of the interface in biotrophic symbiosis as they relate to nutrient transport. New Phytol. 114:1-38.

Smith, S.E., Gianinazzi-Pearson, V., Koide, R. and Cairney, J.W. 1994. Nutrient transport in mycorrhizas: structure, physiology and consequences for efficiency of the symbiosis. In: Management of Mycorrhizas in Agriculture, Horticulture and Forestry. AD Robson, LK Abbott and N Malajczuk (eds.), The Netherlands, Kluwer Academics Publishers. pp. 103-113.

Smith, S.E. and Read, D.J. 1995. Mycorrhizal symbiosis. $2^{\text {nd }}$ edition. Academic Press, London.

Smith, S.E. and Gianinazzi-Pearson, V. 1988. Physiological interactions between symbionts in vesicular-arbuscular mycorrhizal plants. Annual Review of Plant Physiology and Plant Molecular Biology. 39:221-244.

Smith, S.E. and Read, D.J. 1997. Mycorrhizal Symbiosis. 2nd ed. Academic Press, London. pp. 605.

Stewart, G.R. and Press, M.C. 1990. The physiology and biochemistry of parasitic angiosperms. Annual Review of Plant Physiology and Plant Molecular Biology. 41:127-151.

Stintzi, A., Heitz, T., Prasad, V., Wiedemann-Merdinoglu, S., Kauffmann, S., Geoffroy, P., Legrand, M. and Fritig, B. 1993. Plant pathogenesis-related proteins and their role in defense against pathogens. Biochem. 75:687-706.

Tester, M., Smith, S.E. and Smith, F.A. 1987. The phenomenon of “nonmycorrhizal” plants. Can. J. bot. 65:419-431.

Tisserant, B., Gianinazzi-Pearson, V., Gianinazzi, S. and Gollotte, A. 1993. In Planta histochemical staining of fungal alkaline phosphate activity for the analysis of efficient arbuscular mycorrhizal infection. Mycol. Res. 97:245-25.
Tommerup, I.C. and Sivasithamparam, K. 1990. Zygospores and asexual spores of Gigaspora decipiens, an arbuscular mycorrhizal fungus. Mycol. Res. 94:897-900.

Trappe, J.M. 1996. What is a mycorrhiza? Proceedings of the $4^{\text {th }}$ European Symposium on Mycorrhizae, Grandad, Spain. EC Report EUR 19728. pp. 3-9.

Van Loon, L.C., Pierpont, W.S., Boller, T. and Conejero, V. 1994. Recommendation for naming plant pathogenesis-related proteins. Plant Molecular Biology Reporter. 12:245-264.

Varma, A. 1998. Mycorrhiza-the friendly fungi: What we know, what should we know, and how do we know? In: Mycorrhiza Manual. A Varma (ed.), Springer-Verlag, Berlin. pp.1-24.

Varma, A. 1999. Function and applications of arbuscular mycorrhizal fungi in arid and semi-arid soils. In: Mycorrhiza: Structure, Function, Molecular Biology and Biotechnology. A Varma and B Hock (eds.), Springer-Verlag, Germany, $2^{\text {nd }}$ edition. pp. 521-556.

Varma, A. and Bonfante, P. 1994. Utilization of cell wall-related carbohydrates by ericoid mycorrhizal endophytes. Symbiosis.16: 301-313.

Varma, A., Verma, S., Sudha, Sahay, N.S, Butehorn, B. and Franken, P. 1999. Piriformospora indica, a cultivable plant growth promoting root endophyte. Appl. and Environ. Microbiol. 65:2741-2744.

Varma, A., Singh, A., Sudha, Sahay, N.S., Sharma, J., Roy, A., Kumari, M., Rana, D., Thakran, S., Deka, D., Bharti, K., Hurek, T., Blechert, O., Rexer, K-H, Kost, G., Hahn, A., Maier, W., Walter, M., Strack, D. and Kranner, I. 2001. Piriformospora indica: an axenically culturable mycorrhiza-like endosymbiotic fungus. In: The Mycota IX. B Hock (ed.), Springer-Verlag, Berlin, Heidelberg. pp. $125-150$.

Varma, A., Singh, Ar., Sudha, Sahay, NS., Kumari, M., Bharati, K., Sarbhoy, A.K., Maier, W., Walter, M.H., Strack, D., Franken, P., Singh, An., Malla, R. and Hurek, T. 2002. Piriformospora indica: A plant stimulator and pathogen inhibitor arbuscular mycorrhizalike fungus. In: Microorganisms in Bioremediation. DK Markandey and NR Markandey (eds.), Capital Book Company, New-Delhi, India. pp. 71-89.

Verma, S., Varma, A., Rexer, K-H, Hassel, A., Kost, G., Sarabhoy, A., Bisen, P., Butenhorn, B. and Franken, P. 1998. Piriformospora indica, gen. et sp. nov., a new root colonizing fungus. Mycologia. 90:896-903.

Vierheilig, H., Alt, M., Neuhaus, J.M., Boller, T. and Wiemken, A. 1993. Colonization of tansgenic Nicotiana tabacum chitinase, by the root pathogen Rhizoctonia solani and by the mycorrhizal symbiont Glomus mosseae. Molecular Plant Microbe Interactions. 6:261-264.

Walton, J.D. 1994. Deconstructing the cell wall. Plant Physiol. 104:1113-1118.

Warcup, J.H. and Talbot, P.H.B. 1967. Perfect states of Rhizoctonias associated with orchids. New Phytol. 66:631-641.

Weiß, M. and Oberwinkler, F. 2001. Phylogenetic relationships in Auriculariales and related groups-hypotheses derived from nuclear ribosomal DNA sequences. Mycol. Res. 105:403-415.

Wilson, J.M. and Tommerup, I.C. 1992. Interactions between fungal symbionts: VA mycorrhzae. In: Mycorrhizal functioning. MF Allen (ed.), Chapman and Hall, NewYork. pp.198-248.

Wright, S.F. and Upadhaya, A. 1996. Extraction of an abundant and unusual protein from soil and comparison with hyphal protein of arbuscular mycorrhizal fungi. Soil Sci. 161:575-586. 